\title{
O gênero Ocotea (Lauraceae) no estado do Paraná, Brasil
}

\author{
The genus Ocotea (Lauraceae) in Parana State, Brazil
}

\author{
Marcelo Leandro Brotto ${ }^{1,3}$, Armando Carlos Cervi $^{2}$ \& Élide Pereira dos Santos ${ }^{2}$
}

\begin{abstract}
Resumo
Este trabalho apresenta o estudo taxonômico das espécies de Ocotea (Aubl.) no estado do Paraná, Sul do Brasil. São fornecidos chave de identificação, descrições, ilustrações e comentários, que incluem distribuição geográfica, habitat, estado de conservação e época de floração e frutificação. O estudo confirmou 31 espécies de Ocotea no estado do Paraná. A Floresta Atlântica tem o maior número de espécies (26) sendo onze endêmicas, seguida pela Floresta com Araucária (14) com uma endêmica, Floresta Estacional (11), Cerrado (7) com duas endêmicas e Campos (1). Duas espécies correm risco de extinção local. Ocotea daphnifolia (Meisn.) Mez e Ocotea velutina (Nees) Rohwer são citadas pela primeira vez no Paraná.
\end{abstract}

Palavras-chave: Floresta Atlântica, Lauraceae, Ocotea, Paraná, taxonomia.

\begin{abstract}
This work presents a taxonomic study of species of Ocotea (Aubl.) in Parana state, southern Brazil. Identification key, descriptions, illustrations and comments that include geographic distribution, habitat, conservation status and time of flowering and fruiting are provided. The study confirmed 31 species of Ocotea in Parana state. The Atlantic Forest has the largest number of species (26) of which eleven are endemic, followed by Araucaria Forest (14) with one endemic, Semideciduous Seasonal Forest (11), Savannah (7) with two endemic and Fields (1). Two species are at risk of local extinction. Ocotea daphnifolia (Meisn.) Mez and Ocotea velutina (Nees) Rohwer are first mentioned in Parana.
\end{abstract}

Key words: Atlantic Forest, Lauraceae, Ocotea, Parana state, taxonomy.

\section{Introdução}

Lauraceae Juss. é uma família de árvores e arbustos, predominantemente tropical, sendo bem representada na América, Ásia, Austrália, Madagascar e poucos representantes na África (van der Werff \& Richter 1996). Na região Neotropical, está entre as famílias que mais contribuem para a riqueza de espécies de plantas em diferentes comunidades, especialmente nas florestas de terras baixas ou em altitudes intermediárias e sobre solos pobres (Gentry 1988). Compoem as Lauraceae cerca de 50 gêneros e 2500-3000 espécies (van der Werff \& Richter 1996). No Brasil, ocorrem 23 gêneros e 434 espécies (Quinet et al. 2012).

$\mathrm{O}$ gênero Ocotea foi descrito por Aublet (1775) tendo como espécie-tipo Ocotea guianensis Aubl., caracterizado por árvores ou arbustos com flores unissexuadas ou bissexuadas, estames com anteras 4-locelares, locelos arranjados em dois pares sobrepostos, um par de glândulas na base dos filetes dos estames da série III e estaminódios da série IV em geral pouco desenvolvidos. É um gênero muito variável morfologicamente servindo como última opção para espécies que não são prontamente acomodadas em outros gêneros (van der Werff 1991). Ocotea é o maior gênero no Neotrópico com pelo menos 300 espécies distribuídas do México e Sul da Flórida até a Argentina, das quais 170 ocorrem no Brasil (van der Werff 1991; Rohwer 1993; Quinet et al. 2012).

No estado do Paraná o gênero Ocotea tem representantes em praticamente todas as formações florestais e campestres. Segundo Roderjan et al. (2001) algumas espécies de Ocotea aparecem entre as dominantes no estrato arbóreo da Floresta Ombrófila Densa e Floresta Ombrófila Mista.

\footnotetext{
'Museu Botânico Municipal, R. Ostoja Roguski s/n' , 80210-390, Curitiba, PR, Brasil.

${ }^{2}$ Universidade Federal do Paraná, Depto. Botânica, C.P. 19031, 81531-999, Curitiba, PR, Brasil.

${ }^{3}$ Autor para correspondência: mabrotto@smma.curitiba.pr.gov.br
} 
Segundo Scheer \& Blum (2011), nas florestas do Paraná Ocotea está entre os gêneros mais ricos, aparecendo em $2^{\circ}$ lugar com 11 espécies na Floresta Ombrófila Mista e em $3^{\circ}$ lugar com 18 spp. e 8 spp. na Floresta Ombrófila Densa e Floresta Estacional Semidecidual, respectivamente.

Apesar de sua grande importância a família é insuficientemente conhecida no Paraná. Os primeiros estudos taxonômicos referidos para o estado são relativos aos gêneros Ocotea (VattimoGil 1956a, 1956b), Ocotea e Cinnamomum (Vattimo-Gil 1962) e outros (Vattimo-Gil 1979). Desde então uma lacuna de 30 anos separou-os dos estudos mais recentes de Zanon et al. (2009), que trataram o gênero Nectandra para o estado, de Brotto et al. (2009), que trataram diversos gêneros na flórula do Morro dos Perdidos, localizado na Serra do Mar, e de Brotto et al. (2010) e Brotto \& Baitello (2012), que descreveram duas novas espécies de Ocotea no Paraná. Na lista de espécies da flora do Brasil, Quinet et al. (2012) reconhecem para o estado do Paraná 66 espécies de Lauraceae, distribuídas em 12 gêneros. Ocotea está representada por 30 espécies, das quais 29 ocorrem no bioma Mata Atlântica e dez no Cerrado.

A falta de um trabalho taxonômico atualizado sobre o gênero Ocotea no Paraná, a escassez de coletas e as determinações equivocadas dos espécimes, têm dificultado a identificação das espécies. Buscando sanar essas lacunas, o presente estudo teve por objetivo apresentar um estudo taxonômico das espécies de Ocotea no estado do Paraná, aprofundando o conhecimento sobre a diversidade do gênero no estado e contribuindo para o conhecimento da flora do Paraná e do Brasil.

\section{Material e Métodos}

O estado do Paraná está situado na região Sul do Brasil, entre as coordenadas $22^{\circ} 29^{\prime} 30^{\prime \prime}-26^{\circ} 41^{\prime} 00^{\prime \prime}$ $\mathrm{S}$ e $48^{\circ} 02^{\prime} 24^{\prime \prime}-54^{\circ} 37^{\prime} 38^{\prime \prime} \mathrm{W}$. Apresenta área de $199.323 \mathrm{~km}^{2}$, ocupando $2,5 \%$ da superfície total do país. Está dividido em cinco grandes unidades fitogeográficas: Floresta Ombrófila Densa (Floresta Atlântica), Floresta Ombrófila Mista (Floresta com Araucária), Floresta Estacional Semidecidual (Floresta Estacional), Savana (Cerrado) e Estepe (Campos). A diversificação ambiental, resultante de múltiplos fatores, permite o desenvolvimento de várias formações, entre elas: Floresta Ombrófila Densa (FOD) das Terras Baixas, Submontana, Montana, Altomontana e Aluvial; Floresta Ombrófila Mista (FOM) Montana e Aluvial; Floresta Estacional Semidecidual (FES) Submontana e Aluvial; Estepe; Savana; Formações Pioneiras com Influência Marinha, Fluviomarinha e Fluviolacustre; e Refúgios Vegetacionais (Roderjan et al. 2001).

Foram analisadas as coleções de Lauraceae (2450 exsicatas) depositadas nos herbários EFC; FUEL; HBR; HCF; HFC; HFIE; HUCP; HUEM; HUPG; MBM; MO; RB; SP, SPF; SPSF e UPCB. As siglas sublinhadas referem-se a herbários não indexados, os demais seguem Holmgren \& Holmgren (1998). Excursões para reconhecimento das espécies e coleta de espécimes de Ocotea foram realizadas pelo primeiro autor, totalizando 85 viagens entre os anos de 2006 a 2012, com 167 espécimes coletados férteis representando 20 espécies. O material fértil foi herborizado e incorporado no acervo do herbário UPCB, com duplicatas enviadas aos herbários FUEL, MBM, SPSF, RB e NY. O material selecionado indicado no texto segue o critério de um exemplar por unidade fitogeográfica, segundo a classificação de Roderjan et al. (2001), exceto quando foram necessárias outras exsicatas para completar as descrições e ilustrações. Para a lista de coletores foi selecionado um espécime por município paranaense. As ilustrações foram produzidas pelo primeiro autor, com o auxílio de microscópio estereoscópico, em nanquim sobre papel vegetal, posteriormente digitalizadas. $\mathrm{O}$ estado de conservação das espécies foi avaliado apenas para o território paranaense e seguiu os critérios da IUCN versão 3.1 (2001).

A identificação dos táxons e a consulta aos nomes das espécies, basiônimos e sinônimos foi feita a partir dos trabalhos clássicos de Nees Von Esenbeck (1833, 1836), Meissner (1864, 1866) e Mez (1889), bem como dos trabalhos VattimoGil (1956a, 1956b, 1962, 1979), Rohwer (1986), Quinet e Andreata (2002), Baitello (2003) e Assis (2009). A terminologia morfológica utilizada para o indumento foi baseada em Lawrence (1951) e para as inflorescências em Weberling (1989). As demais seguiram Quinet e Andreata (2002), Baitello (2003) e Assis (2009).

\section{Resultados e Discussão}

O estudo revelou a grande riqueza específica do gênero Ocotea no estado do Paraná, sendo confirmadas 31 espécies, das quais dez são andróginas, dezenove dióicas e duas gimnodióicas. A Floresta Ombrófila Densa é a unidade fitogeográfica com maior número de espécies (26), seguida pela Floresta Ombrófila Mista (14), Floresta Estacional 
Semidecidual (11), Savana (7) e Estepe (1). São exclusivas da FOD as espécies Ocotea aciphylla (Nees \& Mart.) Mez, O. brachybotrya (Meisn.) Mez, O. daphnifolia (Meisn.) Mez, O. dispersa (Nees \& Mart.) Mez, O. lanata (Nees \& Mart.) Mez, O. lobbii (Meisn.) Rohwer, O. marumbiensis Brotto \& Baitello, O. notata (Nees \& Mart.) Mez, $O$. paranaensis Brotto, Baitello, Cervi \& E.P. Santos, $O$. teleiandra (Meisn.) Mez e O. vaccinioides (Meisn.) Mez; da FOM apenas $O$. nutans (Nees) Mez é endêmica e da Savana são exlusivas $O$. velloziana (Meisn.) Mez e O. velutina (Nees) Rohwer. Ocupam o dossel 25 espécies e seis o sub-bosque. Quanto ao risco de extinção local, duas espécies são categorizadas como Em Perigo Crítico (CR) e outras sete espécies como Em Perigo (EN), segundo os critérios da IUCN. Todas as demais espécies estão em categorias com menores riscos (Tab. 1). Ocotea daphnifolia (Meisn.) Mez e Ocotea velutina (Nees) Rohwer são citadas pela primeira vez no Paraná.

\section{Chave para espécies de Ocotea no estado do Paraná}

1. Flores bissexuadas.

2. Folhas com domácias.

3. Lâminas com reticulação laxa, domácias axilares e extra-axilares.

4. Folhas com face abaxial enrugada ou plissada; hipantos internamente glabros; frutos longamente ovalados a quase elipsoides 6. O. daphnifolia

4'. Folhas com face abaxial não enrugada ou plissada; hipantos internamente tomentosos; frutos elipsoides 29. O. vaccinioides

3'. Lâminas com reticulação densa, domácias apenas axilares.

5. Inflorescências glabras

15. O. marumbiensis

5'. Inflorescências pubérulas.

6. Inflorescências aureo-pubérulas; tépalas estreito-elípticas; filetes dos estames das séries I e II com $1 / 2$ a $1 / 3$ do compr. das anteras de ápice agudo 10. O. indecora

6'. Inflorescências ferrugíneo-pubérulas; tépalas ovalado-elípticas; filetes dos estames das séries I e II tão longos quanto as anteras de ápice obtuso.

7. Folhas subopostas para o ápice do ramo; domácias cobertas por tricomas alvos; hipantos conspícuos, internamente tomentosos 4. O. catharinensis

7'. Folhas alternas em todo o ramo; domácias cobertas por tricomas ferrugíneos; hipantos inconspícuos, internamente glabros 22. O. porosa

2'. Folhas sem domácias.

8. Folhas agrupadas no ápice dos ramos e alternas na base.

9. Folhas com face abaxial, ramos e inflorescências lanosas

11. O. lanata

9'. Folhas com face abaxial, ramos e inflorescências glabras.

10. Folhas subopostas para o ápice dos ramos; nervura primária imersa na face adaxial 23. O. prolifera

10'. Folhas subverticiladas para o ápice dos ramos; nervura primária subsaliente na face adaxial 20. O. odorifera

8'. Folhas não agrupadas no ápice do ramos, alternas ou subopostas em todo o ramo.

11. Folhas subopostas com ápice obtuso ou arredondado; inflorescências botrióides 14. O. lobbii

11'. Folhas alternas com ápice agudo ou acuminado; inflorescências tirsóides.

12. Folhas com base fortemente revoluta, reticulação densa; hipantos conspícuos .....

12'. Folhas com base não revoluta, reticulação laxa; hipantos inconspícuos 1. O. aciphylla 18. O. nunesiana

1'. Flores unissexuadas.

13. Folhas com domácias.

14. Domácias axilares e extra-axilares.

15. Folhas com face abaxial enrugada ou plissada; hipantos internamente glabros; frutos longamente ovalados a quase elipsoides 6. O. daphnifolia

15'. Folhas com face abaxial não enrugada ou plissada; hipantos internamente tomentosos; frutos elipsoides 29. O. vaccinioides 
14'. Domácias apenas axilares.

16. Inflorescências glabrescentes 13. O. laxa

16'. Inflorescências pubérulas ou tomentosas.

17. Inflorescências tomentosas; tépalas tomentosas na face abaxial; pedicelos 1-1,5 mm de compr.

18. Folhas com face abaxial aureo-pubescentes; estames com filetes glabrescentes ...

8. O. dispersa

18'. Folhas com face abaxial ferrugíneo-tomentosas; estames com filetes tomentosos ...

16. O. nectandrifolia

17'. Inflorescências pubérulas; tépalas glabrescentes ou pubérulas na face abaxial; pedicelos 2-3 mm de compr.

19. Hipantos tomentosos internamente

5. O. corymbosa

19'. Hipantos glabrescentes internamente.

20. Folhas com reticulação densa na face adaxial

25. O. pulchella

20 '. Folhas com reticulação laxa na face adaxial 28. O. tristis

13’. Folhas sem domácias.

21. Folhas glabras ou glabrescentes na face abaxial.

22. Estames das séries I e II com 0,8-1,7 mm e da série III com 1-1,7 mm de compr.

23. Folhas com reticulação laxa, obscura na face adaxial.

24. Estames das séries I e II com filetes de $1 / 2$ a $1 / 3$ do compr. das anteras

3. O. brachybotrya

24'. Estames das séries I e II com filetes de $1 / 4 \mathrm{a}^{1 / 5}$ do compr. das anteras

27. O. teleiandra

23'. Folhas com reticulação densa a subdensa, conspícua na face adaxial.

25. Estames das séries I e II com filetes de $1 / 2 \mathrm{a}^{1 / 3} \mathrm{do}$ compr. das anteras, glabrescentes ou tomentosos.

26. Pecíolos 0,3-1,2 cm de compr.; hipantos pubérulos internamente; cúpulas trompetiformes de margem hexlobada 2. O. bicolor

26'. Pecíolos 1,2-2 cm de compr.; hipantos tomentosos internamente; cúpulas hemisféricas de margem simples

7. O. diospyrifolia

$25^{\prime}$. Estames das séries I e II com filetes um pouco mais curtos ou tão longos quanto as anteras, glabros.

27. Ramos não lustrosos; pecíolos 1-2 cm de compr., achatados; hipantos pubérulos internamente; pistilos com estigma discóide 17. O. notata

27'. Ramos lustrosos; pecíolos 0,3-0,6 cm de compr., canaliculados; hipantos glabros internamente; pistilos com estigma subcapitado 19. O. nutans

22'. Estames das séries I e II com 1,8-2,8 mm e da série III com 1,8-2,8 mm de compr.

28. Pecíolos 1-2,5 cm de compr.; cúpulas infundibuliformes 24. O. puberula

28'. Pecíolos 0,3-1 cm de compr; cúpulas obcônicas ou sub-hemisféricas.

29. Lâminas com relação 4-4,5 compr. $\times 1$ larg.; pistilos 2,5-3,5 mm de compr.

30. Folhas com ápice agudo; 6-10 pares de nervuras secundárias; flores pubérulas ou glabrescentes 12. O. lancifolia

30'. Folhas com ápice acuminado; 4-6 pares de nervuras secundárias; flores tomentosas 21. O. paranaensis

29’. Lâminas com relação 2,7-3,3 compr. × 1 larg.; pistilos 2-2,5 mm de compr.

31. Folhas elípticas ou obovadas, coriáceas; pecíolos engrossados ca. $0,2 \mathrm{~cm}$ de espessura 9. O. glaziovii

31'. Folhas elípticas ou ovalado-elípticas; cartáceo-coriáceas, pecíolos não engrossados ca. $0,1 \mathrm{~mm}$ de espessura 26. O. silvestris

21'. Folhas tomentosas na face abaxial.

32. Folhas ovadas; pecíolos $1-2 \mathrm{~mm}$ de compr; hipantos glabrecentes internamente; tépalas glabras 30. O. velloziana

32'. Folhas elípticas ou obovadas; pecíolos 0,5-1 mm de compr; hipantos tomentosos internamente; tépalas tomentosas 31. O. velutina 
Tabela 1 - Espécies de Ocotea no estado do Paraná, habitat, risco de extinção (IUCN) no estado, unidade fitogeográfica de ocorrência amplitude altimétrica de ocorrência, posição sociológica e período de floração/frutificação. LC - preocupação menor, EN - em perigo, CR - criticamente em perigo; NT - quase ameaçada; FOD - Floresta Ombrófila Densa, FOM Floresta Ombrófila Mista, FES - Floresta Estacional Semidecidual, E - Estepe, S - Savana, RV - Refúgio Vegetacional, FPI - Formação Pioneira de Influência, a - Altomontana, $\mathrm{m}$ - Montana, s - Submontana, tb - Terras Baixas, al - Aluvial, fl - Fluvial, ma - Marinha; do - Dossel, sb - Sub-bosque.

Table 1 - Species of Ocotea in the state of Paraná, habitat, endangered status (IUCN), altitudinal occurrence, sociological condition and flowering/ fruiting period. LC - least concern, EN - endangered, CR - critically endangered, NT - near threatened; FOD - Rain Forest, FOM - Araucaria Forest, FES - Semideciduous Forest, E - Steppe, S - Savanna, RV - Vegetational Refuge, FPI - Determinant Pioneer Formation, a - Upper Montane, $\mathrm{m}$ - Montane, $\mathrm{s}$ - Submontane, tb - Lowlands, al - Alluvial, $\mathrm{fl}$ - Fluvial, ma - Marine; do - Canopy, sb - Understorey.

\begin{tabular}{|c|c|c|c|c|c|c|c|c|c|c|c|c|c|c|c|c|}
\hline \multirow[b]{2}{*}{ Espécie } & \multirow[b]{2}{*}{ IUCN } & \multirow[b]{2}{*}{ Habitat } & \multirow[b]{2}{*}{ Altitude } & \multirow[b]{2}{*}{ PS } & \multicolumn{12}{|c|}{ Floração (•) e Frutificação $(\diamond)$} \\
\hline & & & & & $\mathbf{J}$ & $\mathbf{F}$ & $\mathbf{M}$ & $\mathbf{A}$ & $\mathbf{M}$ & $\mathbf{J}$ & $\mathbf{J}$ & $\mathbf{A}$ & $\mathbf{S}$ & $\mathbf{O}$ & $\mathbf{N}$ & D \\
\hline Ocotea aciphylla & $\mathrm{LC}$ & $\mathrm{FOD}(\mathrm{tb}, \mathrm{s}, \mathrm{m})$ & $3-900$ & do & $\diamond$ & $\diamond$ & $\diamond$ & $\diamond$ & $\diamond$ & $\diamond$ & $\bullet \diamond$ & • & • & • & $\diamond$ & $\diamond$ \\
\hline Ocotea bicolor & $\mathrm{LC}$ & FOD (tb, m, a); FOM; FES & $3-1600$ & do & $\bullet \diamond$ & $\bullet \diamond$ & $\diamond$ & $\diamond$ & $\bullet \diamond$ & $\bullet \diamond$ & $\diamond$ & $\diamond$ & $\bullet \diamond$ & $\diamond$ & $\bullet \diamond$ & $\cdot \diamond$ \\
\hline Ocotea brachybotrya & $\mathrm{EN}$ & FOD $(\mathrm{tb}, \mathrm{s})$ & $3-300$ & $\mathrm{sb}$ & $\diamond$ & $\diamond$ & & & & & & & & $\bullet \diamond$ & $\bullet \diamond$ & $\diamond$ \\
\hline Ocotea catharinensis & $\mathrm{LC}$ & FOD $(\mathrm{s}, \mathrm{m}) ; \mathrm{FOM} ; \mathrm{FES}$ & $50-1100$ & do & $\bullet \diamond$ & $\bullet \diamond$ & $\bullet \diamond$ & $\bullet \diamond$ & $\bullet \diamond$ & $\bullet \diamond$ & $\diamond$ & $\diamond$ & $\diamond$ & $\bullet \diamond$ & $\bullet \diamond$ & $\cdot \diamond$ \\
\hline Ocotea corymbosa & $\mathrm{LC}$ & FES; S & $265-800$ & do & • & & & $\diamond$ & $\diamond$ & $\bullet \diamond$ & $\diamond$ & $\diamond$ & $\diamond$ & $\bullet \diamond$ & $\bullet \diamond$ & $\cdot \diamond$ \\
\hline Ocotea daphnifolia & NT & FOD $(\mathrm{s}, \mathrm{m})$ & $420-950$ & $\mathrm{sb}$ & • & & & & & & & & & $\diamond$ & $\bullet$ & • \\
\hline Ocotea diospyrifolia & $\mathrm{LC}$ & FOM; FES & $240-1100$ & do & $\diamond$ & $\diamond$ & $\diamond$ & $\diamond$ & $\diamond$ & & & $\bullet$ & $\bullet$ & $\bullet \diamond$ & $\bullet \diamond$ & $\cdot \diamond$ \\
\hline Ocotea dispersa & $\mathrm{LC}$ & $\mathrm{FOD}(\mathrm{tb}, \mathrm{s}, \mathrm{al})$ & $5-200$ & $\mathrm{sb}$ & & & - & - & - & • & • & $\diamond$ & $\diamond$ & $\diamond$ & $\diamond$ & \\
\hline Ocotea glaziovii & $\mathrm{LC}$ & $\mathrm{FOD}(\mathrm{tb}, \mathrm{s}, \mathrm{m}), \mathrm{FOM}$ & $10-1000$ & do & & & - & • & - & $\bullet \diamond$ & $\diamond$ & $\diamond$ & $\diamond$ & $\diamond$ & $\diamond$ & $\diamond$ \\
\hline Ocotea indecora & $\mathrm{LC}$ & FOD (s, m); FOM; FES & $10-1100$ & do & $\diamond$ & $\diamond$ & $\diamond$ & $\bullet \diamond$ & $\bullet \diamond$ & $\bullet \diamond$ & $\bullet \diamond$ & $\bullet \diamond$ & $\diamond$ & $\diamond$ & $\diamond$ & $\diamond$ \\
\hline Ocotea lanata & $\mathrm{CR}$ & FOD (s) & 200 & $\mathrm{sb}$ & - & $\bullet$ & - & - & & $\diamond$ & & & & & & \\
\hline Ocotea lancifolia & $\mathrm{LC}$ & FOD (a); FOM; S & $550-1500$ & do & & & - & - & $\bullet \diamond$ & $\bullet \diamond$ & $\diamond$ & $\diamond$ & $\diamond$ & $\diamond$ & $\diamond$ & \\
\hline Ocotea laxa & NT & FOD (s, m); FOM; FES & $485-800$ & do & $\diamond$ & $\diamond$ & $\diamond$ & $\diamond$ & $\bullet \diamond$ & & & & $\bullet$ & $\bullet \diamond$ & $\bullet \diamond$ & $\bullet \diamond$ \\
\hline Ocotea lobbii & $\mathrm{EN}$ & FOD $(\mathrm{tb})$ & $3-10$ & do & & & & & $\bullet \diamond$ & • & • & - & - & & & \\
\hline Ocotea marumbiensis & $\mathrm{EN}$ & $\mathrm{FOD}(\mathrm{m})$ & $700-1230$ & do & - & - & - & • & $\bullet \diamond$ & $\bullet \diamond$ & $\bullet \diamond$ & $\bullet \diamond$ & $\bullet \diamond$ & $\bullet \diamond$ & $\diamond$ & \\
\hline Ocotea nectandrifolia & NT & FOD $(\mathrm{s}, \mathrm{m}) ; \mathrm{FOM}$ & $400-1100$ & do & • & - & $\diamond$ & $\diamond$ & $\diamond$ & $\diamond$ & $\diamond$ & $\diamond$ & $\diamond$ & $\diamond$ & & - \\
\hline Ocotea notata & EN & $\mathrm{FOD}(\mathrm{m})$ & 900 & $\mathrm{sb}$ & $\cdot$ & & & & & $\diamond$ & $\diamond$ & $\diamond$ & & & & - \\
\hline Ocotea nunesiana & NT & FOD $(\mathrm{s}, \mathrm{m}) ; \mathrm{FOM}$ & $50-1100$ & do & $\diamond$ & $\diamond$ & $\diamond$ & $\diamond$ & $\diamond$ & $\diamond$ & $\diamond$ & $\bullet \diamond$ & - & $\bullet \diamond$ & $\bullet \diamond$ & $\bullet \diamond$ \\
\hline Ocotea nutans & $\mathrm{LC}$ & FOM & $800-970$ & do & $\diamond$ & - & - & - & $\bullet \diamond$ & $\bullet \diamond$ & $\diamond$ & $\diamond$ & $\diamond$ & $\diamond$ & $\diamond$ & $\diamond$ \\
\hline Ocotea odorifera & $\mathrm{LC}$ & FOD (tb, s, m); FOM; FES; S & $10-1000$ & do & $\bullet \diamond$ & $\bullet \diamond$ & $\bullet \diamond$ & $\diamond$ & $\diamond$ & $\diamond$ & $\diamond$ & $\diamond$ & $\diamond$ & $\diamond$ & $\diamond$ & $\diamond$ \\
\hline Ocotea paranaensis & EN & FOD $(\mathrm{m})$ & $850-975$ & do & $\diamond$ & & - & - & - & & $\diamond$ & $\diamond$ & $\diamond$ & $\diamond$ & $\diamond$ & $\diamond$ \\
\hline Ocotea porosa & $\mathrm{LC}$ & FOD (m, a); FOM; FES & $620-1650$ & do & $\bullet \diamond$ & $\bullet \diamond$ & $\bullet \diamond$ & $\bullet \diamond$ & $\diamond$ & $\diamond$ & $\diamond$ & $\bullet \diamond$ & $\bullet \diamond$ & $\bullet \diamond$ & $\bullet \diamond$ & $\bullet \diamond$ \\
\hline Ocotea prolifera & $\mathrm{EN}$ & FOD (s); FES & $350-600$ & do & • & • & $\bullet \diamond$ & $\diamond$ & $\diamond$ & $\diamond$ & $\diamond$ & $\diamond$ & $\diamond$ & $\diamond$ & $\diamond$ & $\bullet \diamond$ \\
\hline Ocotea puberula & $\mathrm{LC}$ & FOD (s, m); FOM; FES & $3-1100$ & do & $\diamond$ & $\diamond$ & • & - & - & - & $\bullet \diamond$ & $\bullet \diamond$ & $\bullet \diamond$ & $\bullet \diamond$ & $\bullet \diamond$ & $\cdot \diamond$ \\
\hline Ocotea pulchella & $\mathrm{LC}$ & $\begin{array}{l}\text { FOD (tb, s, m, a); FPI } \\
\text { (ma, fl); FOM, S }\end{array}$ & $3-1320$ & do & $\diamond$ & • & $\bullet \diamond$ & $\bullet$ & $\bullet \diamond$ & $\diamond$ & $\diamond$ & $\diamond$ & $\bullet \diamond$ & $\diamond$ & $\diamond$ & $\diamond$ \\
\hline Ocotea silvestris & $\mathrm{LC}$ & FOD (s, m); FOM; FES & $250-1100$ & do & - & - & - & $\bullet \diamond$ & $\bullet \diamond$ & $\diamond$ & $\diamond$ & $\diamond$ & $\diamond$ & $\diamond$ & $\diamond$ & $\bullet \diamond$ \\
\hline Ocotea teleiandra & $\mathrm{LC}$ & FOD (tb, s, m, al); FPI (fl) & $3-1080$ & $\mathrm{sb}$ & $\cdot \diamond$ & $\bullet \diamond$ & $\diamond$ & $\diamond$ & $\diamond$ & $\diamond$ & $\bullet \diamond$ & $\bullet \diamond$ & $\bullet \diamond$ & $\bullet \diamond$ & $\bullet \diamond$ & $\cdot \diamond$ \\
\hline Ocotea tristis & $\mathrm{LC}$ & FOD (a), RV, S, E & $1.030-1820$ & do & $\bullet \diamond$ & • & - & • & $\bullet \diamond$ & $\bullet \diamond$ & $\bullet \diamond$ & $\cdot \diamond$ & $\diamond$ & $\diamond$ & $\diamond$ & $\diamond$ \\
\hline Ocotea vaccinioides & NT & $\mathrm{FOD}(\mathrm{m}, \mathrm{a})$ & $820-1530$ & do & • & • & - & $\diamond$ & $\diamond$ & $\diamond$ & $\diamond$ & $\diamond$ & $\diamond$ & $\diamond$ & $\diamond$ & - \\
\hline Ocotea velloziana & $\mathrm{EN}$ & $\mathrm{S}$ & $265-1000$ & do & & & • & • & • & • & $\bullet \diamond$ & $\diamond$ & $\diamond$ & $\diamond$ & $\diamond$ & \\
\hline Ocotea velutina & $\mathrm{CR}$ & $\mathrm{S}$ & 400 & do & & & & & • & & $\diamond$ & $\diamond$ & & & & \\
\hline
\end{tabular}


1. Ocotea aciphylla (Nees \& Mart) Mez, Jahrb. Königl. Bot. Gart. Berlin 5: 243. 1889.

Fig. 1a1-a8

Árvores, $18 \mathrm{~m}$ alt.; ramos subcilíndricos, aureo-tomentosos. Folhas alternas; pecíolo 0,7-1,5 cm compr., canaliculado, tomentoso; lâmina 6-17 × 1,5-4 cm, lanceolada ou elíptica, ápice acuminado, base cuneada, fortemente revoluta, face adaxial glabra, lustrosa, reticulação densa, inconspícua, nervuras planas, face abaxial aureoserícea, reticulação densa, inconspícua, nervura primária saliente, secundárias subsalientes, 6-9 pares, ângulo de divergência $25^{\circ}-50^{\circ}$, nervação broquidódroma, domácias ausentes. Inflorescências axilares e subterminais; tirsóide 2-10 cm compr., multiflora, aureo-tomentosa. Flores bissexuadas; pedicelo ca. $2 \mathrm{~mm}$ compr.; hipanto conspícuo, internamente tomentoso; tépalas ca. 2,2 $\mathrm{mm}$ compr., elípticas ou estreito-elípticas, tomentosas em ambas as faces, papilas no ápice; estames das séries I e II 0,9-1,1 mm compr., filetes mais curtos que as anteras, tomentosos, anteras ovaladas, ápice agudo, inconspicuamente papilosas, locelos introrsos; estames da série III ca. 1,2 mm compr., filetes tão longos quanto as anteras, tomentosos, anteras retangulares, ápice truncado, locelos superiores laterais e inferiores lateral-extrorsos; estaminódios da série IV 0,6-0,9 $\mathrm{mm}$ compr., clavados, tomentosos; pistilo $1,7-2 \mathrm{~mm}$ compr., glabro, ovário elipsoide, estilete ca. $1 / 2$ do ovário, estigma subcapitado. Cúpulas ca. $2 \times 1,9 \mathrm{~cm}$, subhemisféricas, lenticeladas, infladas na região central, margem simples. Frutos ca. 3,1 $\times 1,7 \mathrm{~cm}$, elipsoides. Material selecionado: Adrianópolis, 20.X.2009, fl., M.L. Brotto \& G. Vasconcellos 386 (FUEL, MBM, NY, RB, SPSF, UPCB). Guaraqueçaba, 7.XII.1972, fr., G.G. Hatschbach 30951 (HUPG, MBM, UPCB). Paranaguá, 27.V.1980, fr., C.V. Roderjan 65 (EFC, UPCB). Pontal do Paraná, 10.IX.1965, fl., G.G. Hatschbach 12746 (MBM, RB, UPCB). Tunas do Paraná, 4.X.1999, fl., J.M. Silva \& L.M. Abe 3082 (FUEL, HFIE, MBM, SP, UPCB).

No Paraná Ocotea aciphylla é encontrada na FOD das Terras Baixas, Submontana e Montana, entre 3 e $900 \mathrm{~m}$, ocupando o dossel. A espécie é frequente e amplamente distribuída em sua área de ocorrência, sendo categorizada nos critérios da IUCN (2001) como Menor Preocupação (LC). Em material vivo a coloração das flores varia de alva a creme, exalando odor suave, e os frutos maduros são pretos. A madeira apresenta odor acentuado. Entre as espécies com flores bissexuadas é a única com folhas seríceas de base fortemente revoluta. Floresce de julho a outubro e frutifica de novembro a julho.
2. Ocotea bicolor Vattimo-Gil, Rodriguésia 1819(30-31): 302. 1956.

Fig. 1b1-b7

Árvores, $12 \mathrm{~m}$ alt.; ramos cilíndricos, glabros. Folhas alternas; pecíolo $0,3-1,2 \mathrm{~cm}$ compr., ca. $0,1 \mathrm{~cm}$ espessura, subcanaliculado, glabro; lâmina 5-11 × 1,5-3 cm, estreito-elíptica ou elíptica, ápice acuminado, base cuneada, face adaxial glabra, lustrosa, reticulação subdensa, conspícua, nervuras planas, face abaxial glabra, reticulação densa, nervura primária subsaliente, secundárias planas, 6-10 pares, ângulo de divergência $30^{\circ}-65^{\circ}$, nervação broquidódroma, domácias ausentes. Inflorescências axilares; tirsóide 3-13 cm compr., multiflora, glabra. Flores unissexuadas; estaminadas com pedicelo 1,5-3 $\mathrm{mm}$ compr.; hipanto inconspícuo, internamente pubérulo; tépalas 1,6-2,2 mm compr., ovalado-elípticas, glabras em ambas as faces, papilas incospícuas no ápice; estames das séries I e II 1-1,3 mm compr., filetes $1 / 2$ a $1 / 3$ do comprimento das anteras, glabrescentes, anteras ovalado-triangulares a ovalado-quadrangulares, ápice agudo, glabras, locelos introrsos; estames da série III 1,1-1,5 mm compr., filetes pouco mais curtos que as anteras, glabrescentes, anteras retangulares, ápice truncado, locelos superiores introrsos e inferiores lateralextrorsos; estaminódios da série IV inconspícuos ou ausentes; pistiloide filiforme ou ausente; pistiladas com estaminódios ca. $0,6 \mathrm{~mm}$ compr., pistilo ca. 1,5 $\mathrm{mm}$ compr., glabro, ovário globoso, estilete muito curto ou ausente, estigma capitado. Cúpulas ca. $1 \times$ $1 \mathrm{~cm}$, trompetiformes, margem hexalobada. Frutos ca. $2 \times 1,2 \mathrm{~cm}$, elipsoides ou globosos.

Material selecionado: Adrianópolis, 10.II.2009, fl. (ð)), M.L. Brotto et al. 285 (MBM, NY, RB, SPSF, UPCB). Castro, 27.I.1989, fl., G.G. Hatschbach \& A. Manosso 52574 (MBM, SPSF, UPCB). Curitiba, 27.XII.2009, fl. (), M.L. Brotto 410 (FUEL, MBM, NY, RB, SPSF, UPCB).Guaratuba, 17.VI.2008, fr., M.L. Brotto \& F. Marinero 152 (MBM, RB, UPCB). Quatro Barras, 22.I.2009, fl., M.L. Brotto \& R.C. Dorneles 279 (FUEL, MBM, NY, RB, SPSF, UPCB).

No Paraná Ocotea bicolor é encontrada na FOD das Terras Baixas, Montana e Altomontana, FOM e FES, entre 3 e 1.600 m, ocupando o dossel. A espécie é amplamente distribuída no estado com exceção do terceiro planalto, sendo frequente na FOD e FOM e rara na FES, por isso é categorizada nos critérios da IUCN (2001) como Menor Preocupação (LC). Em material vivo a coloração das flores varia entre branca, alva e creme, exalando odor suave, e os frutos maduros são pretos. A madeira apresenta odor desagradável, justificando o nome popular de canela-merda ou canela-fedida. Rohwer (1986) considerou que $O$. bicolor é 


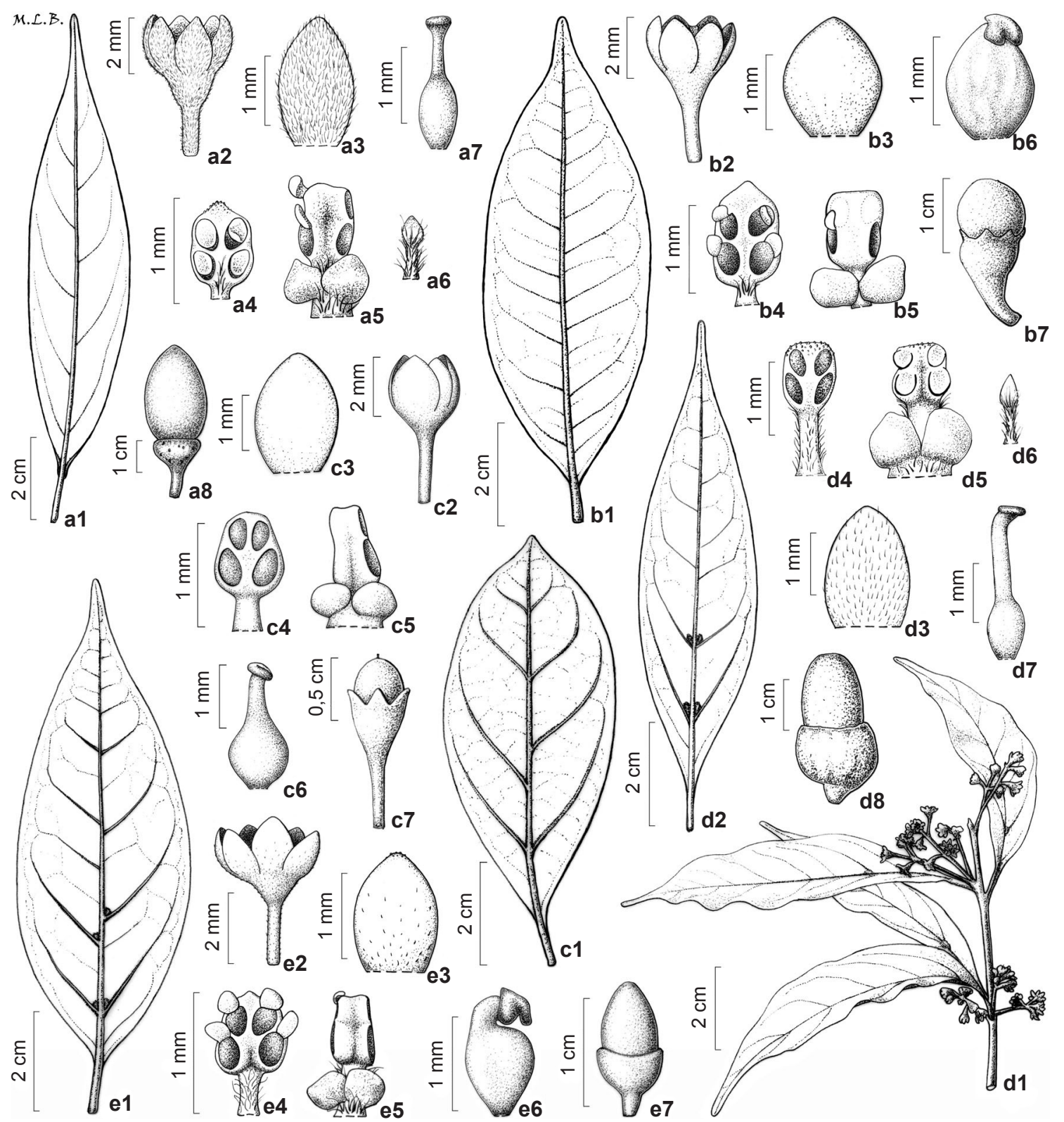

Figura 1 - a. Ocotea aciphylla (Nees \& Mart.) Mez - a1. folha (face abaxial); a2. flor; a3. tépala; a4. estame série I; a5. estame série III; a6. estaminódio série IV; a7. pistilo; a8. fruto. b. O. bicolor Vattimo-Gil-b1. folha (face abaxial); b2. flor (ठ); b3. tépala; b4. estame série I; b5. estame série III; b6. pistilo; b7. fruto. c. O. brachybotrya (Meisn.) Mez-c1. folha (face abaxial); c2. flor ( $\left.)^{\Uparrow}\right)$; c3. tépala; c4. estame série I; c5. estame série III; c6. pistilo; c7. fruto. d. O. catharinensis Mez - d1. ramo com flores; d2. folha (face abaxial); d3. tépala; d4. estame série I; d5. estame série III; d6. estaminódio série IV; d7. pistilo; d8. fruto. e. O. corymbosa (Meisn.) Mez-e1. folha (face abaxial); e2. fflor ( 1 ); e3. tépala; e4. estame série I; e5. estame série III; e6. pistilo; e7. fruto. (a1,a8 Roderjan 65; a2-a7 Hatschbach 12746; b1-b5 Brotto 285; b6 Brotto 410; b7 Brotto 152; c1-c5 Silva 4398; c6-c7 Hatschbach 72737; d1 Brotto 662; d2,d8 Brotto 347; d3-d7 Jaster 44; e1,e7 Hatschbach 16983; e2-e5 Hatschbach 5275; e6 Hatschbach 13256).

Figure 1 - a. Ocotea aciphylla (Nees \& Mart.) Mez - a1. leaf (abaxial surface); a2. flower; a3. tepal; a4. stamen series I; a5. stamen series III; a6. staminode series IV; a7. pistil; a8. fruit. b. O. bicolor Vattimo-Gil - b1. leaf (abaxial surface); b2. flower ( ()); b3. tepal; b4. stamen series I; b5. stamen series III; b6. pistil; b7. fruit. c. O. brachybotrya (Meisn.) Mez-c1. leaf (abaxial surface); c2. flower (§̋); c3. tepal; c4. stamen series I; c5. stamen series III; c6. pistil; c7. fruit. d. O. catharinensis Mez - d1. flowering branch; d2. leaf (abaxial surface); d3. tepal; d4. stamen series I; d5. stamen series III; d6. staminode series IV; d7. pistil; d8. fruit. e. O. corymbosa (Meisn.) Mez - e1. leaf (abaxial surface); e2. flower (đ); e3. tepal; e4. stamen series I; e5. stamen series III; e6. pistil; e7. fruit. (a1,a8 Roderjan 65; a2-a7 Hatschbach 12746; b1-b5 Brotto 285; b6 Brotto 410; b7 Brotto 152; c1-c5 Silva 4398; c6-c7 Hatschbach 72737; d1 Brotto 662; d2,d8 Brotto 347; d3-d7 Jaster 44; e1,e7 Hatschbach 16983; e2-e5 Hatschbach 5275; e6 Hatschbach 13256). 
sinônima de Ocotea corymbosa (Meisn.) Mez. As principais características que as diferenciam são flores e inflorescências pilosas, pistilos com estiletes maiores, pecíolos com $0,8-2,0 \mathrm{~cm}$ de comprimento e cúpulas de margem simples em $O$. corymbosa enquanto que $O$. bicolor tem flores e inflorescências glabras, pistilos com estiletes muito curtos ou ausentes, pecíolos menores e cúpulas de margem hexalobada. Em material desidratado as folhas adquirem duas tonalidades com a nervura central tornando-se avermelhada. Floresce de novembro a fevereiro, em maio, junho e setembro, com pico de floração entre novembro e fevereiro, frutifica durante $o$ ano todo.

3. Ocotea brachybotrya (Meisn.) Mez, Jahrb. Königl. Bot. Gart. Berlin 5: 332. 1889.

Fig. 1c1-c7

Árvores, $8 \mathrm{~m}$ alt.; ramos cilíndricos, glabros. Folhas alternas; pecíolo $0,5-1 \mathrm{~cm}$ compr., canaliculado, glabrescente; lâmina 5-11 × 2-4 $\mathrm{cm}$, elíptica, ápice caudado, base cuneada, face adaxial glabra, lustrosa, reticulação obscura, nervura primária subsaliente, secundárias planas, face abaxial glabra, reticulação laxa, nervuras subsalientes, secundárias 5-8 pares, ângulo de divergência $45^{\circ}-65^{\circ}$, nervação broquidódroma, domácias ausentes. Inflorescências axilares; tirsóide 1,5-6 cm compr., pauciflora, glabrescente. Flores unissexuadas; estaminadas com pedicelo 2-2,5 mm compr.; hipanto inconspícuo, internamente pubérulo; tépalas 2-2,2 $\mathrm{mm}$ compr., elípticas, glabras em ambas as faces, papilas inconspícuas na margem e no ápice; estames das séries I e II ca. 1,2 mm compr., filetes $1 / 2 \mathrm{a}^{1 / 3}$ do comprimento das anteras, glabros, anteras ovaladas, ápice obtuso, glabras, locelos introrsos; estames da série III ca. 1,2 mm compr., filetes $1 / 2$ do comprimento das anteras, glabros, anteras ovalado-retangulares, ápice truncado, locelos laterais; estaminódios da série IV ausentes; pistiloide ca. 1,5 mm compr., estipiforme, glabro; pistiladas com estaminódios ca. $0,8 \mathrm{~mm}$ compr., pistilo ca. 2 $\mathrm{mm}$ compr., glabro, ovário globoso, estilete mais curto que o ovário, estigma lobado. Cúpulas ca. $1,2 \times 0,6 \mathrm{~cm}$, trompetiformes, margem hexalobada. Frutos ca. $0,5 \times 0,5 \mathrm{~cm}$, globosos, ápice mucronado. Material selecionado: Adrianópolis, 17.X.2005, fl. (ठ), J.M. Silva et al. 4398 (MBM). Guaraqueçaba, 28.XI.2001, fl. (ㅇ) e fr., G.G. Hatschbach et al. 72737 (FUEL, MBM, SPSF).

No Paraná Ocotea brachybotrya é encontrada na FOD das Terras Baixas e Submontana, entre 3 e $300 \mathrm{~m}$, ocupando o sub-bosque. A espécie é rara no estado, entretanto, essa raridade pode estar relacionada com seu limite austral de ocorrência, a região limítrofe entre o Leste do Paraná e Sudeste de São Paulo, por isso é categorizada nos critérios da IUCN (2001) como Em Perigo (EN B1ab(iii)). Em material vivo a coloração das flores é creme e os frutos quando maduros apresentam cúpulas vermelhas ou vináceas. Assemelha-se a $O$. laxa (Nees) Mez, que apresenta folhas com domácias nas axilas das nervuras, e também a $O$. teleiandra, que apresenta frutos maiores com cúpulas de margem simples. Floresce de outubro a novembro e frutifica de outubro a fevereiro.

4. Ocotea catharinensis Mez, Bot. Jahrb. Syst. 30, Beibl. 67: 19. 1901.

Fig. $1 \mathrm{~d} 1-\mathrm{d} 8$

Árvores, $30 \mathrm{~m}$ alt.; ramos subcilíndricos, glabrescentes. Folhas subopostas para o ápice dos ramos e alternas para a base; pecíolo 0,5-1 $\mathrm{cm}$ compr., canaliculado, glabrescente; lâmina 6-12 × 1,5-3,5 cm, lanceolada ou elíptica, ápice acuminado, base cuneada, margem ondulada, face adaxial glabra, lustrosa, bulada sobre as domácias, reticulação densa, nervuras planas, face abaxial glabrescente, reticulação densa, nervuras subsalientes, secundárias 5-8 pares, ângulo de divergência $25^{\circ}-60^{\circ}$, nervação camptódromabroquidódroma, domácias nas axilas basais, cobertas por tricomas alvos. Inflorescências axilares e subterminais; botrióide $2-4,5 \mathrm{~cm}$ compr., pauciflora, ferrugíneo-pubérula. Flores bissexuadas; pedicelo 2-3 mm compr.; hipanto conspícuo, internamente tomentoso; tépalas 2-2,6 mm compr., ovalado-elípticas, face abaxial pubérula, face adaxial tomentosa, papilas na margem; estames das séries I e II 1,3-1,8 mm compr., filetes tão longos quanto as anteras, pubérulos, anteras ovalado-elípticas, ápice obtuso, papilosas, locelos introrsos; estames da série III 1,6-1,8 mm compr., filetes iguais ou pouco mais longos que as anteras, pubérulos, anteras retangulares, ápice truncado, locelos superiores laterais e inferiores lateral-extrorsos; estaminódios da série IV ca. 0,8 mm compr., clavados, tomentosos; pistilo 2,4-2,6 mm compr., glabro, ovário elipsoide, estilete igual ou mais longo que o ovário, estigma subcapitado. Cúpulas ca. 1,8 × 1,2 $\mathrm{cm}$, hemisféricas, lenticeladas, margem simples. Frutos ca. 1,2 $\times 1 \mathrm{~cm}$, elipsoides.

Material selecionado: Campina Grande do Sul, 13.XI.1960, fr., G.G. Hatschbach 7426 (MBM, RB).Guaraqueçaba, 8.XII.1995, fr., S.R. Ziller \& W. Maschio 1015 (EFC, MBM, SPSF). Guaratuba, 12.VI.1996, fl., C.B. Jaster \& A.C. 
Svolenski 44 (EFC, MBM); 19.IV.2009, fr., M.L. Brotto 347 (MBM, NY, RB, SPSF, UPCB). Quatro Barras, 7.V.2011, fl., M.L. Brotto 662 (MBM, RB, SP, UPCB).

No Paraná Ocotea catharinensis é encontrada na FOD Submontana e Montana, na FOM e na FES, entre 50 e $1.100 \mathrm{~m}$, ocupando o dossel. A espécie é amplamente distribuída no Leste do estado, sendo frequente na FOD e rara na FOM e FES. Entre as Lauraceae foi a mais visada na exploração da Serra do Mar. No Parque Estadual das Lauráceas podem ser encontradas populações notáveis dessa espécie em floresta primária no que se refere à abundância e porte dos indivíduos. Também apresenta boa regeneração em florestas secundárias em estágio médio e avançado de sucessão. Ela é categorizada nos critérios da IUCN (2001) como Menor Preocupação (LC), apesar de estar na lista brasileira de extinção (MMA 2008). Em material vivo a coloração das flores é cremeesverdeada, exalando odor suave, e os frutos que levam um ano para se desenvolverem, quando maduros, adquirem coloração preta com cúpulas levemente avermelhadas. A madeira apresenta odor acentuado. Vegetativamente pode ser confundida com O. porosa (Nees \& Mart.) Barroso, da qual difere pela disposição das folhas subopostas para o ápice do ramo e pelas domácias com tricomas alvos, e também de $O$. indecora (Schott.) Mez, da qual pode ser diferenciada por caracteres das flores e inflorescências. Floresce de outubro a junho e frutifica de maio a abril.

5. Ocotea corymbosa (Meisn.) Mez, Jahrb. Königl. Bot. Gart. Berlin 5: 321. 1889. Fig. 1e1-e7

Árvores, $17 \mathrm{~m}$ alt.; ramos subcilíndricos, aureo-pubérulos. Folhas alternas; pecíolo 0,8-2 cm compr., ca. 0,1 cm espessura, canaliculado, pubérulo; lâmina 5-10 × 1,5-4 cm, estreito-elíptica ou ovadoelíptica, ápice acuminado ou caudado, base cuneada, revoluta, face adaxial glabra, reticulação subdensa, nervura primária subsaliente, secundárias planas, face abaxial glabra, reticulação densa, nervura primária saliente, secundárias subsalientes, 6-9 pares, ângulo de divergência $30^{\circ}-60^{\circ}$, nervação broquidódroma, domácias nas axilas, cobertas por tricomas aureos. Inflorescências axilares; tirsóide 3-9 cm compr., multiflora, aureo-pubérula. Flores unissexuadas; estaminadas com pedicelo ca. $2 \mathrm{~mm}$ compr.; hipanto conspícuo, internamente tomentoso; tépalas 1,4-1,8 mm compr., ovalado-elípticas, face abaxial glabescente, face adaxial pubérula, papilas incospícuas no ápice; estames das séries I e II ca. 1,1 mm compr., filetes $1 / 2$ do comprimento das anteras, pubérulos, anteras ovalado-quadrangulares, ápice agudo, glabras, locelos introrsos; estames da série III 1-1,2 mm compr., filetes pouco mais curtos que as anteras, tomentosos, anteras retangulares, ápice truncado, locelos superiores lateral-introrsos e inferiores lateral-extrorsos; estaminódios da série IV e pistilóide ausentes; pistiladas com estaminódios ca. 0,6 mm compr., pistilo ca. 1,3 mm compr., glabro, ovário elipsoide, estilete muito curto, estigma capitado. Cúpulas ca. 0,8 ×0,5 cm, hemisféricas, margem simples. Frutos ca. $0,9 \times 0,4 \mathrm{~cm}$, ovalados, ápice mucronado.

Material selecionado: Campo Mourão, 8.XII.1965, fl. (q), G.G. Hatschbach et al. 13256 (MBM). Cianorte, 26.VIII.1967, fr., G.G. Hatschbach 16983 (MBM). Londrina, 8.X.1992, fl., F. Chagas e Silva 1583 (FUEL, HFC). Sengés, 12.XII.1958, fl. (ठ̊), G.G. Hatschbach \& R.B. Lange 5275 (MBM, SP, UPCB). Tuneiras do Oeste, 17.I.2004, fl., M.G. Caxambu 269 (HCF, MBM).

No Paraná Ocotea corymbosa é encontrada na FES e Savana, entre 265 e 800 m, ocupando o dossel. A espécie é amplamente distribuída no segundo e terceiro planaltos do Paraná, com provável limite austral de ocorrência sob $24^{\circ}$ de latitude, embora seja citada para Santa Catarina e Rio Grande do Sul, por isso é categorizada nos critérios da IUCN (2001) como Menor Preocupação (LC). Em material vivo a coloração das flores varia de creme a amarela e os frutos maduros são pretos. Floresce de outubro a janeiro e em junho, e frutifica de abril a dezembro.

6. Ocotea daphnifolia (Meisn.) Mez, Jahrb. Königl. Bot. Gart. Berlin 5: 307. 1889. Fig. 2a1-a8 Árvores, gimnodióica, $8 \mathrm{~m}$ alt.; ramos cilíndricos, glabrescentes. Folhas alternas; pecíolo 0,3-0,8 cm compr., glabrescente; lâmina 3,5-10 $\times 1-2,5 \mathrm{~cm}$, estreito-elíptica ou obovado-elíptica, ápice agudo, base cuneada, face adaxial glabra, reticulação laxa, inconspícua, nervura primária subsaliente, secundárias planas, face abaxial enrugada ou plissada, glabra, reticulação laxa, nervura primária saliente, secundárias subsalientes, 6-9 pares, ângulo de divergência $45^{\circ}-80^{\circ}$, nervação broquidódroma, domácias nas axilas e extraaxilares, não cobertas por tricomas. Inflorescências axilares; tirsóide 2-3 cm compr., pauciflora, aureoglabrescentes. Flores bissexuadas; pedicelo 2-2,5 mm compr.; hipanto inconspícuo, internamente glabro; tépalas 1,6-1,9 mm compr., elípticas, face abaxial tomentosa, face adaxial papilosa e tomentosa; estames das séries I e II ca. 1,2 mm compr., filetes mais curtos que as anteras, glabros, 
anteras ovalado-quadrangulares, ápice obtuso, glabras, locelos introrsos; estames da série III ca. 1,5 mm compr., filetes mais curtos que as anteras, glabrescentes, anteras ovalado-retangulares, ápice truncado, glabras, locelos superiores laterais e inferiores lateral-extrorsos; estaminódios da série IV ca. $0,8 \mathrm{~mm}$ compr., clavados, pubérulos; pistilo ca. 1,7 mm compr., glabro, ovário globoso, estilete longo, estigma subcapitado; Flores unissexuadas; pistiladas com estaminódios ca. 0,7 mm compr.; pistilo ca. 1,5 mm compr., glabro, ovário globoso, estilete curto, estigma capitado. Cúpulas $0,7 \times 0,7$ cm, obcônicas, margem simples. Frutos $2,1 \times 1,1$ $\mathrm{cm}$, longamente ovalados a quase elipsoides.

Material selecionado: Adrianópolis, 25.XI.2008, fl. (ð), M.L. Brotto \& G. Vasconcellos 267 (MBM, RB, SPSF, UPCB). Bocaiúva do Sul, 30.XI.1960, fl. (ㅇ), G.G. Hatschbach 7506 (MBM, RB). Campina Grande do Sul, 15.I.1969, fl., G.G. Hatschbach \& C. Koczicki 20777 (MBM). Morretes, 14.X.2008, fr., M.L. Brotto \& F. Marinero 208 (MBM, SPSF, UPCB).

Ocotea daphnifolia é citada pela primeira vez no Paraná, onde é encontrada na FOD Submontana e Montana, entre 420 e 950 m, aparentemente ocupando o sub-bosque. A espécie é amplamente distribuída em sua área de ocorrência embora não seja frequente, com provável limite austral de ocorrência sob $25^{\circ} 50^{\prime}$ de latitude, por isso é categorizada nos critérios da IUCN (2001) como Quase Ameaçada (NT). Em material vivo a coloração das flores varia entre alva, creme e amarela. Das espécies de Ocotea que ocorrem no estado apenas $O$. daphnifolia e $O$. vaccinioides são gimnodióicas e apresentam domácias axilares e extra-axilares. $O$. daphnifolia difere desta pelas folhas com a face abaxial enrugada ou plissada, pelo ângulo de divergência das nervuras secundárias em relação à primária nitidamente mais aberto, pelos hipantos internamente glabros e pelos frutos longamente ovalados a quase elipsoides. Floresce de novembro a janeiro e frutifica em outubro.

7. Ocotea diospyrifolia (Meisn.) Mez, Jahrb. Königl. Bot. Gart. Berlin 5: 374. 1889.

Fig. 2b1-b8

Árvores, $20 \mathrm{~m}$ alt.; ramos subcilíndricos, alvo-pubérulos. Folhas alternas; pecíolo 1,2-2 cm compr., canaliculado, pubérulo; lâmina 7-15 × 2-4 cm, elíptica, ápice acuminado, base cuneada, margem ondulada, revoluta, face adaxial glabra, reticulação subdensa, conspícua, nervura principal subsaliente, secundárias planas, face abaxial glabra, reticulação subdensa, nervura primária saliente, secundárias subsalientes, 6-10 pares, ângulo de divergência $30^{\circ}-60^{\circ}$, nervação broquidódroma, domácias ausentes. Inflorescências axilares ou subterminais; tirsóide 3-15 cm compr., multiflora, glabrescente. Flores unissexuadas; estaminadas com pedicelo ca. 2,5 mm compr.; hipanto inconspícuo, internamente tomentoso; tépalas $1,4-1,8 \mathrm{~mm}$ compr., ovalado-elípticas, glabra em ambas as faces; estames das séries I e II ca. 1-1,7 mm compr., filetes $1 / 3$ a $1 / 5$ do comprimento das anteras, tomentosos, anteras ovalado-quadrangulares, ápice agudo, inconspicuamente papiloso, locelos introrsos; estames da série III 1,1-1,3 mm compr., filetes $1 / 2$ a $1 / 3$ do comprimento das anteras, tomentosos, anteras retangulares, ápice truncado, glabras, locelos superiores lateral-introrsos e inferiores lateralextrorsos; estaminódios da série IV ca. 0,5 mm compr., tomentosos; pistiloide ausente; pistiladas com estaminódios ca. $0,7 \mathrm{~mm}$ compr.; pistilo ca. 1,8 mm compr., glabro, ovário elipsoide, estilete curto, estigma capitado. Cúpulas 1,5 × 1,5 cm, hemisféricas, margem simples. Frutos 1,4 × 1,1 cm, elipsoides.

Material selecionado: Curiúva, 16.X.1999, fl., R.A.G. Viani \& J.B. Baitello 19 (FUEL, HFC, MBM). Londrina, 18.XII.2002, fr., D.A Estevan 298 (FUEL, MBM, RB, SPSF). Mangueirinha, 6.XII.1989, fl. (ठ̋), G.G. Hatschbach \& V. Nicolack 53682 (MBM, SPSF, UPCB). Pato Branco, 21.XI.1995, fl., S.R. Ziller \& W. Maschio 1026 (HFC, MBM, SPSF). Santa Mariana, 20.X.1998,

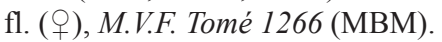

No Paraná Ocotea diospyrifolia é encontrada na FES e FOM, entre 240 e 1.100 m, ocupando o dossel. A espécie é frequente e amplamente distribuída no segundo e terceiro planaltos do Paraná sendo categorizada nos critérios da IUCN (2001) como Menor Preocupação (LC). Em material vivo a coloração das flores varia de creme a amarela e os frutos maduros são pretos. Assemelhase a Ocotea puberula (Rich.) Nees, que apresenta flores com hipantos internamente glabros, filetes proporcionalmente maiores em relação as anteras e frutos com cúpulas infundibuliformes, enquanto que $O$. diospyrifolia apresenta hipantos tomentosos, filetes proporcionalmente menores em relação as anteras e frutos com cúpulas hemisféricas. Floresce de agosto a dezembro e frutifica de outubro a maio.

8. Ocotea dispersa (Nees \& Mart.) Mez, Jahrb. Königl. Bot. Gart. Berlin 5: 357. 1889.

Fig. 2c1-c6

Árvores, $15 \mathrm{~m}$ alt.; ramos cilíndricos, aureotomentosos. Folhas alternas; pecíolo $0,3-0,5 \mathrm{~cm}$ compr., subcanaliculado, tomentoso; lâmina 4-11 


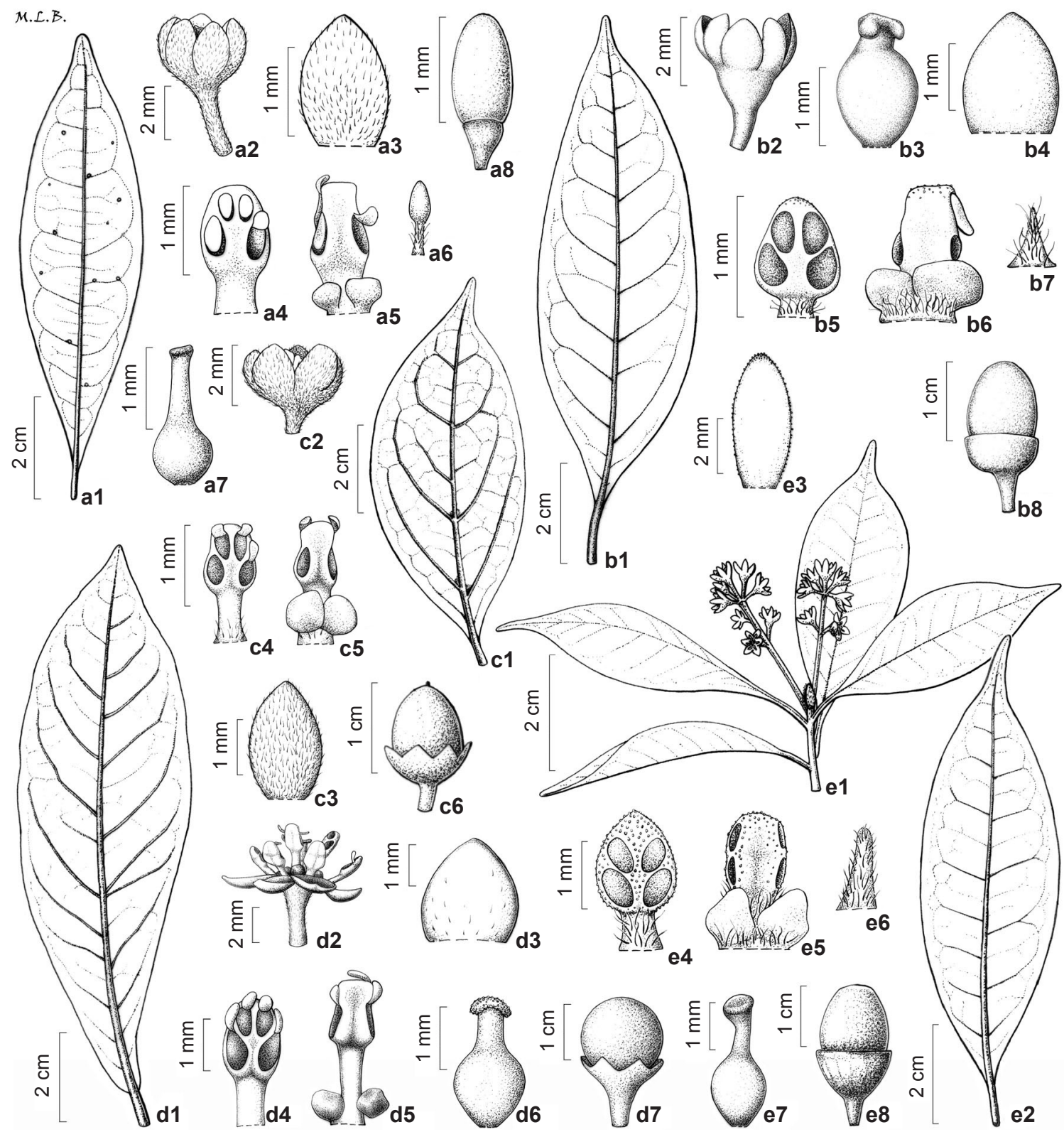

Figura 2 - a. Ocotea daphnifolia (Meisn.) Mez-a1. folha (face abaxial); a2. flor; a3. tépala; a4. estame série I; a5. estame série III;

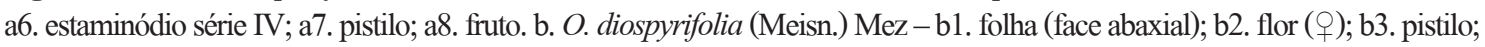
b4. tépala; b5. estame série I; b6. estame série III; b7. estaminódio série IV; b8. fruto. c. O. dispersa (Nees \& Mart.) Mez-c1. folha (face abaxial); c2. lor (); c3. tépala; c4. estame série I; c5. estame série III; c6. fruto. d. O. glaziovii Mez-d1. folha (face abaxial); d2. lor ( $($ )); d3. tépala; d4. estame série I; d5. estame série III; d6. pistilo; d7. fruto. e. O. indecora (Schott) Mez - e1. ramo com flores; e2. folha (face abaxial); e3. tépala; e4. estame série I; e5. estame série III; e6. estaminódio série IV; e7. pistilo; e8. fruto. (a1,a8 Brotto 208; a2-a7 Brotto 267; b1,b8 Estevan 298; b2-b3 Tomé 1266; b4-b7 Hatschbach 53682; c1,c6 Hatschbach 32278; c2-c5 Silva 3580; d1,d7 Ribas 7095; d2-d5 Brotto 623; d6 Reginato 695; e1,e3-e7 Hatschbach 47829; e2,e8 Brotto 11).

Figure 2 - a. Ocotea daphnifolia (Meisn.) Mez-a1. leaf (abaxial surface); a2. flower; a3. tepal; a4. stamen series I; a5. stamen series III; a6. staminode series IV; a7. pistil; a8. fruit. b. O. diospyrifolia (Meisn.) Mez-b1. leaf(abaxial surface); b2. flower(\&); b3. pistil; b4. tepal; b5. stamen series I; b6. stamen series III; b7. staminode series IV; b8. fruit. c. $O$. disersa (Nees \& Mart.) Mez - c1. leaf (abaxial surface); c2. lower (ㅇ); c3. tepal; c4. stamen series I; c5. stamen series III; c6. fruit. d. O. glaziovii Mez-d1. leaf (abaxial surface); d2. lower ( $($ ); d3. tepal; d4. stamen series I; d5. stamen series III; d6. pistil; d7. fruit. e. O. indecora (Schott) Mez-e1. flowering branch; e2. leaf (abaxial surface); e3. tepal; e4. stamen series I; e5. stamen series III; e6. staminode series IV; e7. pistil; e8. fruit. (a1,a8 Brotto 208; a2-a7 Brotto 267; b1,b8 Estevan 298; b2-b3 Tomé 1266; b4-b7 Hatschbach 53682; c1,c6 Hatschbach 32278; c2-c5 Silva 3580; d1,d7 Ribas 7095; d2-d5 Brotto 623; d6 Reginato 695; e1,e3-e7 Hatschbach 47829; e2,e8 Brotto 11). 
$\times 1,5-4,5 \mathrm{~cm}$, elíptica, ápice agudo ou curtoacuminado, base cuneada, margem ondulada, face adaxial glabrescente, reticulação densa, nervura primária plana a subsaliente, secundárias planas, face abaxial aureo-pubescente, reticulação densa, nervuras salientes, secundárias 4-6 pares, ângulo de divergência $25^{\circ}-50^{\circ}$, nervação broquidódroma, domácias sem fóveas, inconspícuas. Inflorescências axilares ou subterminais; botrióide ou tirsóide 1,5-5 cm compr., pauciflora, aureo-tomentosa. Flores unissexuadas; estaminadas, pedicelo ca. $1 \mathrm{~mm}$ compr.; hipanto inconspícuo, internamente tomentoso; tépalas 1,7-2,2 mm compr., ovalado-elipticas, face abaxial tomentosa, face adaxial glabra; estames das séries I e II 1-1,5 mm compr., filetes pouco mais curtos que as anteras, glabrescentes, anteras ovalado-retangulares, ápice obtuso, glabras, locelos superiores introrsos e inferiores lateral-introrsos; estames da série III 1,0-1,6 mm compr., filetes tão longos quanto as anteras, glabrescentes, anteras retangulares, ápice truncado, locelos superiores lateral-introrsos e inferiores lateral-extrorsos; estaminódios da série IV inconspícuos ou ausentes; pistiloide filiforme ou ausente; pistiladas com estaminódios 0,5-0,7 mm compr., pistilo ca. 1,5 mm compr., glabro, ovário elipsoide, estilete curto, estigma capitado. Cúpulas ca. $0,5 \times 0,7 \mathrm{~cm}$, sub-hemisféricas, margem hexalobada. Frutos ca. $1 \times 0,7 \mathrm{~cm}$, elipsoides, ápice mucronado. Material selecionado: Antonina, 16.IX.1965, fr., G.G. Hatschbach 12760 (MBM, RB, UPCB). Guaraqueçaba, 4.X.1990, fr., G.G. Hatschbach \& V. Nicolack 54335 (MBM). Guaratuba, 20.III.2002, fl. (ð), J.M. Silva et al. 3580 (MBM, RB). Morretes, 9.VIII.1973, fr., G.G. Hatschbach 32278 (MBM). Paranaguá, 14.VII.1962, fl. (ठ)), G.G. Hatschbach 9199 (MBM, RB, UPCB).

Material adicional: BRASIL. SANTA CATARINA: Garuva, 17.IV.1958, fl. (), R. Reitz 6676 (RB).

No Paraná Ocotea dispersa é encontrada FOD das Terras Baixas, Submontana e Aluvial, entre 5 e 200 m, ocupando o sub-bosque. A espécie é amplamente distribuída em sua área de ocorrência embora não seja frequente, sendo categorizada nos critérios da IUCN (2001) como Menor Preocupação (LC). Em material vivo a coloração das flores é creme e os frutos maduros são pretos com cúpulas vermelhas. Em material desidratado a face abaxial das folhas adquire coloração rubiginosa. Floresce de março a julho e frutifica de agosto a novembro.

9. Ocotea glaziovii Mez, Jahrb. Königl. Bot. Gart. Berlin 5: 281. 1889.

Fig. 2d1-d7

Árvores, $22 \mathrm{~m}$ alt.; ramos angulosos, glabrescentes. Folhas alternas; pecíolo 0,5-1 $\mathrm{cm}$ compr., engrossado ca. $0,2 \mathrm{~cm}$ espessura, subcanaliculado, glabrescente; lâmina 6-16 × 2-6 $\mathrm{cm}$, coriácea, elíptica ou obovada, ápice obtuso, agudo ou acuminado, base cuneada, revoluta, face adaxial glabra, reticulação densa, inconspícua, nervura primária subsaliente, secundárias planas, face abaxial glabra, reticulação densa, nervura primária saliente, secundárias subsalientes, 7-12 pares, ângulo de divergência $40^{\circ}-65^{\circ}$, nervação broquidódroma, domácias ausentes. Inflorescências axilares; tirsóide 3-8 cm compr., multiflora, alvopubérula. Flores unissexuadas; estaminadas com pedicelo ca. $2 \mathrm{~mm}$ compr.; hipanto inconspícuo, internamente pubérulo; tépalas $2-3 \mathrm{~mm}$ compr., ovalado-elípticas, pubérulas em ambas as faces, papilas na margem; estames das séries I e II 2-2,4 mm compr., filetes mais curtos ou tão longos quanto as anteras, glabros, anteras ovalado-retangulares, ápice obtuso, glabras, locelos superiores introrsos e inferiores lateral-introrsos; estames da série III 2-2,8 mm compr., filetes tão longos quanto as anteras, glabrescentes, anteras retangulares, ápice truncado, locelos superiores lateral-introrsos e inferiores lateral-extrorsos; estaminódios da série IV inconspícuos ou ausentes; pistiloide estipiforme, pubérulo; pistiladas com estaminódios 0,6-1,3 mm compr., pistilo ca. 2,5 mm compr., glabro, ovário globoso, estilete curto, estigma capitado, papiloso. Cúpulas $1 \times 1,2 \mathrm{~cm}$, obcônicas, margem simples ou hexalobada. Frutos ca. 1,5 × 1,5 cm, globosos. Material selecionado: Adrianópolis, 27.X.2005, fr., O.S. Ribas \& J.M. Silva 7095 (MBM). Antonina, 27.VI.2007, fl. (ठ̋), P.H. Labiak \& F.B. Matos 3951 (SPSF, UPCB). Jaguariaíva, 17.IV.2011, fl. (ð), M.L. Brotto 623 (MBM, NY, RB, SP, UPCB). Morretes, 2.XII.2009, fr., M.L. Brotto et al. 399 (MBM, RB, SPSF, UPCB). Piraquara,

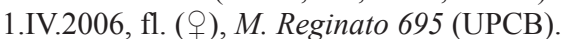

Material adicional: BRASIL. SANTA CATARINA: Blumenau, 23.IV.1953, fl. (中), R. Reitz \& R. Klein 568 (HBR, UPCB). Itajaí, 14.V.1954, fl. (ठ), R. Reitz \& R. Klein 1846 (MBM).

No Paraná Ocotea glaziovii é encontrada na FOD das Terras Baixas, Submontana e Montana e na FOM, entre 10 e 1.000 m, ocupando o dossel. A espécie é amplamente distribuída no estado, com exceção do terceiro planalto, embora não seja frequente, sendo categorizada nos critérios da IUCN (2001) como Menor Preocupação (LC). O material examinado apresentou grande variação no tamanho e forma das folhas e cúpulas dos frutos, sendo possível englobar material-tipo de O. glaziovii e Ocotea pulchra Vattimo-Gil dentro dessa variação. Os tipos citados por Ida de VattimoGil são provenientes de vegetação sobre morros, provavelmente no limite austral de ocorrência de 
O. glaziovii. Nesse habitat a tendência observada foi redução no tamanho das folhas, frutos e não persistência de tépalas na cúpula, características registradas também em habitat de planície litorânea quaternária. Por sua vez, as coletas provenientes de vegetação sobre terreno pouco acidentado ou sobre solos mais férteis apresentaram folhas e frutos maiores com cúpula hexalobada, assim como os tipos de $O$. glaziovii. Será necessário um estudo mais aprofundado para definir a real amplitude desses táxons. No presente estudo $O$. pulchra é tratada como sinônima de $O$. glaziovii. Em material vivo a coloração das flores varia de creme a verde e os frutos maduros apresentam cúpulas vermelhas. Difere de $O$. silvestris Vattimo-Gil pelos pecíolos mais espessos e pelos frutos globosos com cúpulas de margem simples ou hexalobada. Floresce de março a junho e frutifica de junho a dezembro.

10. Ocotea indecora (Schott) Mez, Jahrb. Königl. Bot. Gart. Berlin 5: 249. $1889 . \quad$ Fig. 2 e1-e8

Árvores, $20 \mathrm{~m}$ alt.; ramos com crescimento rítmico, subcilíndricos, glabrescentes. Folhas agrupadas no ápice dos ramos e alternas na base; pecíolo $0,7-1 \mathrm{~cm}$ compr., canaliculado, glabrescente; lâmina 5-11 × 1,5-4,5 cm, elíptica, ápice agudo ou acuminado, base cuneada, margem ondulada, face adaxial glabra, lustrosa, bulada sobre as domácias, reticulação densa, nervura primária subsaliente, secundárias planas, face abaxial glabrescente, reticulação densa, nervura primária saliente, secundárias planas, 5-9 pares, ângulo de divergência $30^{\circ}-70^{\circ}$, nervação camptódromabroquidódroma, domácias nas axilas basais, podendo faltar em algumas folhas, cobertas por tricomas alvos. Inflorescências subterminais, agrupadas ao redor da gema apical tomentosa, subtendidas por brácteas; botrióide 2-5 cm compr., pauciflora, aureo-pubérula. Flores bissexuadas; pedicelo ca. $2 \mathrm{~mm}$ compr.; hipanto conspícuo, internamente tomentoso; tépalas $3,2-4,8 \mathrm{~mm}$ compr., estreito-elípticas, face abaxial pubérula, face adaxial glabrescente, papilas na margem; estames das séries I e II 1,5-2,2 mm compr., filetes $1 / 3$ a $1 / 2$ do comprimento das anteras, tomentosos, anteras ovaladas, ápice agudo, papilosas, locelos introrsos; estames da série III 1,5-2,4 mm compr., filetes mais curtos que as anteras, tomentosos, anteras retangulares, ápice truncado, locelos superiores laterais e inferiores lateral-extrorsos; estaminódios da série IV 1-1,3 mm compr., filiformes, tomentosos; pistilo 2,1-2,7 mm compr., glabro, ovário elipsoide, estilete igual ou pouco mais curto que o ovário, estigma subcapitado. Cúpulas ca. 1,8 $\times 1,6 \mathrm{~cm}$, hemisféricas, margem simples. Frutos ca. $2 \times 1,3 \mathrm{~cm}$, elipsoides.

Material selecionado: Fênix, 3.VI.1963, fl., G.G. Hatschbach 10101 (MBM, RB, SP, UPCB). Guaratuba, 25.I.2007, fr., M.L. Brotto et al. 11 (SPSF, UPCB).Londrina, 7.VII.1989, fl., L.H. Soares e Silva 218 (FUEL, HUEM, UPCB). Morretes, 26.IV.1984, fl., G. G. Hatschbach 47829 (FUEL, RB, SP, UPCB). São João do Triunfo, 8.XI.1967, fr., G.G. Hatschbach 17786 (MBM, RB).

No Paraná Ocotea indecora é encontrada na FOD Submontana e Montana, FOM e FES, entre 10 e $1.100 \mathrm{~m}$, ocupando o dossel. A espécie é amplamente distribuída em todo e estado, sendo mais frequente na FES, por isso é categorizada nos critérios da IUCN (2001) como Menor Preocupação (LC). Em material vivo a coloração das flores varia de alva a creme, exalando um odor suave. A madeira apresenta odor acentuado, sendo confundida com O. catharinensis. Difere desta principalmente pelas inflorescências, anteras das séries I e II e tépalas. Também se assemelha a Ocotea prolifera (Nees \& Mart.) Mez, que apresenta nervura principal imersa na face adaxial das folhas, além das gemas apicais, inflorescências e flores glabras, enquanto que $O$. indecora apresenta nervura principal subsaliente na face adaxial das folhas, além da gemas apicais tomentosas, inflorescências e flores pubérulas. Assemelha-se ainda a $O$. marumbiensis Brotto \& Baitello, que apresenta inflorescências e flores glabras, tépalas ovalado-elípticas, cúpulas trompetiformes a sub-hemisféricas e frutos com $1 \mathrm{~cm}$ de comprimento, enquanto que $O$. indecora apresenta inflorescências e flores pilosas, tépalas estreito-elípticas, cúpulas hemisféricas e frutos com $2 \mathrm{~cm}$ de comprimento. Para a consulta dos sinônimos ver Assis \& Mello-Siva (2010). Floresce de abril a agosto e frutifica de abril a março.

11. Ocotea lanata (Nees \& Mart.) Mez, Jahrb. Königl. Bot. Gart. Berlin 5: 254. 1889.

Fig. 3 a1-a6

Árvores, $11 \mathrm{~m}$ alt.; ramos com crescimento rítmico, cilindricos, ferrugíneo-lanosos. Folhas agrupadas no ápice dos ramos e alternas na base; pecíolo 0,5-1 cm compr., canaliculado, lanoso; lâmina 9-23 × 2,5-6,5 cm, obovada ou elíptica, ápice agudo ou acuminado, base cuneada, revoluta, face adaxial glabrescente, reticulação densa, nervura primária subsaliente, secundárias planas, face abaxial ferrugíneo-lanosa, reticulação densa, nervura primária saliente, secundárias subsalientes, 
9-13 pares, ângulo de divergência $30^{\circ}-70^{\circ}$, nervação broquidódroma, domácias ausentes. Inflorescências subterminais, agrupadas ao redor da gema apical, subtendidas por brácteas; botrióide 3-7 cm compr., pauciflora, ferrugíneo-lanosa. Flores bissexuadas; pedicelo ca. $2 \mathrm{~mm}$ compr.; hipanto inconspícuo, internamente lanoso; tépalas ca. $4 \mathrm{~mm}$ compr., estreito-elípticas, face abaxial lanosa, face adaxial papilosa; estames das séries I e II ca. $2,1 \mathrm{~mm}$ compr., filetes $1 / 5$ do comprimento das anteras, lanosos, anteras ovalado-triangulares, ápice agudo, papilosas, locelos introrsos; estames da série III ca. 1,9 mm compr., filetes mais curtos que as anteras, lanosos, anteras retangulares, ápice truncado, papilosas, locelos superiores laterais, inferiores lateral-extrorsos; estaminódios da série IV ca. $0,9 \mathrm{~mm}$ compr., filiformes, pubérulos; pistilo ca. 2,5 mm compr., glabro, ovário elipsoide, estilete longo, estigma capitado, pubérulo. Cúpulas $1,2 \times$ $1 \mathrm{~cm}$, hemisférica, margem simples. Frutos $1,5 \times$ $1,2 \mathrm{~cm}$, elipsoides.

Material selecionado: Guaratuba, 18.I.1970, f1., G.G. Hatschbach 23359 (MBM, SPF).

Material adicional: BRASIL. SÃO PAULO: Itatiba, 29.VI.2004, fr., R.M. Cerqueira 22 (SPSF). São Paulo, 13.I.1978, fl., M.G.L. Wanderley et al. 122 (MBM).

No Paraná Ocotea lanata é encontrada na FOD Submontana, a $200 \mathrm{~m}$, ocupando o subbosque. A espécie é rara no estado, conhecida por apenas uma coleta, embora sua ocorrência em São Paulo e Santa Catarina sugira uma ampla distribuição no Leste do Paraná, por isso é categorizada nos critérios da IUCN (2001) como Em Perigo Crítico (CR). Em material vivo, a coloração das flores varia entre creme, alva e branca. O indumento lanoso sobre a face abaxial das folhas, ramos jovens e inflorescências é a principal característica dessa espécie. Floresce de janeiro a abril e frutifica em junho.

12.Ocotea lancifolia (Schott) Mez, Jahrb. Königl. Bot. Gart. Berlin 5: 289. $1889 . \quad$ Fig. 3 b1-b8

Árvores, $7 \mathrm{~m}$ alt.; ramos cilíndricos, glabros.

Folhas alternas; pecíolo $0,3-1 \mathrm{~cm}$ compr., $0,1-0,2$ cm espessura; subcanaliculado, glabro; lâmina $4,5-13 \times 1-3 \mathrm{~cm}$, estreito-elíptica ou lanceolada, ápice agudo, base cuneada, revoluta, ambas as faces glabras, reticulação densa, conspícua, nervura principal subsaliente, secundárias planas, 6-10 pares, ângulo de divergência $25^{\circ}-50^{\circ}$, nervação broquidódroma, domácias ausentes. Inflorescências axilares e subterminais; tirsóide 3-12 cm compr., multiflora, aureo-pubérula. Flores unissexuadas, pubérulas ou glabrescentes; estaminadas com pedicelo 1,5-4 mm compr.; hipanto inconspícuo, internamente glabrescente; tépalas $2,5-3 \mathrm{~mm}$ compr., ovalado-elípticas, reflexas, glabrescentes em ambas as faces, papilas inconspícuas no ápice; estames das séries I e II 1,8-2,8 mm compr., filetes tão longos quanto as anteras, glabrescentes, anteras ovalado-retangulares, ápice obtuso, glabras, locelos superiores introrsos e inferiores lateral-introrsos; estames da série III 2-2,8 mm compr., filetes tão longos quanto as anteras, glabros, anteras retangulares, ápice obtuso, locelos superiores lateral-introrsos e inferiores lateral-extrorsos; estaminódios ausentes; pistiloide ca. 2,5-3,3 mm compr., estipiforme, glabrescente; pistiladas com estaminódios $0,7-0,9$ mm compr.; pistilo ca. $2,5 \mathrm{~mm}$ compr., glabrescente, ovário globoso, estilete curto, estigma subcapitado. Cúpulas ca. 0,7 $\times 0,7 \mathrm{~cm}$, obcônicas, margem dupla. Frutos ca. 1,3 ×0,9 cm, elipsoides.

Material selecionado: Campina Grande do Sul, 5.V.2010, fr., M.L. Brotto et al. 440 (FUEL, MBM, RB, SPSF, UPCB). Campo Mourão, 13.V.2005, fl. (†), R.C. Ferreira 28 (HCF, MBM). Jaguariaíva, 14.IV.1962, fl. (ठ) ), G. G. Hatschbach 9082 (MBM, RB, UPCB). Tibagi, 6.IX.2009, fr., M.L. Brotto 374 (MBM, NY UPCB). Tijucas do Sul, 15.II.1976, fl. (đ), R. Kummrow 1081 (MBM, SP, UPCB).

No Paraná Ocotea lancifolia é encontrada na Savana, FOM e FOD Altomontana, entre 550 e $1.500 \mathrm{~m}$, ocupando o dossel. A espécie é amplamente distribuída em remanescentes de Savana no segundo e terceiro planaltos do Paraná, habitando preferencialmente beira de rios. Também pode ser encontrada no primeiro planalto e Serra do Mar onde é rara, por isso é categorizada nos critérios da IUCN (2001) como Menor Preocupação (LC). Em material vivo a coloração das flores varia entre creme, amarelada e esverdeada, e os frutos maduros são roxos. Assemelha-se a O. paranaensis Brotto, Baitello, Cervi e E.P. Santos, da qual difere por características de folhas, flores e frutos. Floresce de março a junho e frutifica de maio a novembro.

13. Ocotea laxa (Nees) Mez, Jahrb. Königl. Bot. Gart. Berlin 5: 381. $1889 . \quad$ Fig. 3 c1-c7

Árvores, $24 \mathrm{~m}$ alt.; ramos cilíndricos, glabrescentes. Folhas alternas; pecíolo $0,5-0,8 \mathrm{~cm}$ compr., canaliculado, glabrescente; lâmina 4-9 $\times$ 1-3 cm, elíptica, ápice agudo ou acuminado, base atenuada, face adaxial glabra, bulada sobre as domácias, reticulação laxa, nervuras planas, face abaxial glabrescente, reticulação laxa, nervura primária saliente, secundárias subsalientes, 3-5 

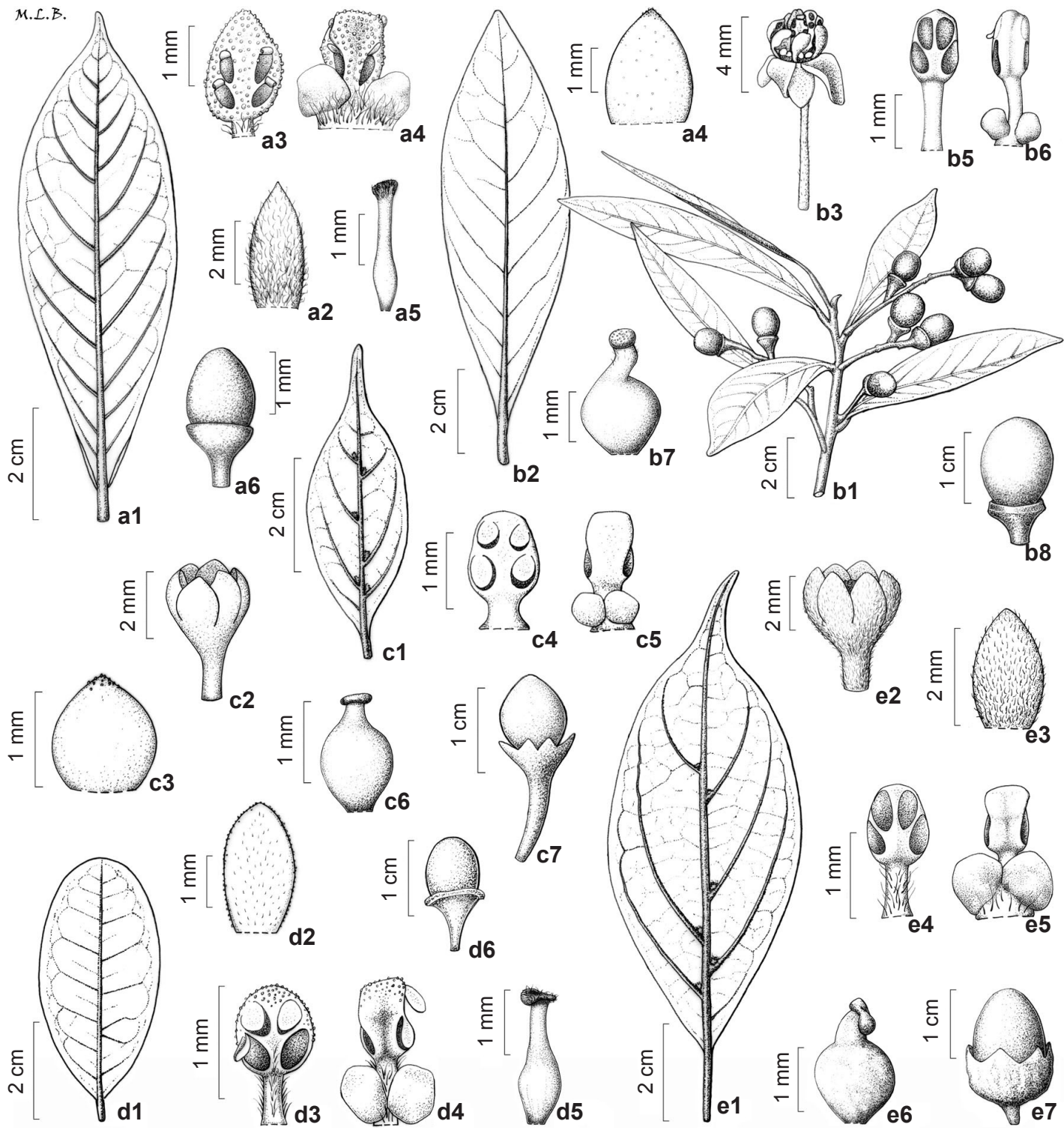

Figura 3 - a. Ocotea lanata (Nees \& Mart.) Mez - a1. folha (face abaxial); a2. tépala; a3. estame série I; a4. estame série III; a5. pistilo; a6. fruto. b. O. lancifolia (Schott) Mez - b1. ramo com frutos; b2. folha (face abaxial); b3. flor (ठ̊); b4. tépala; b5. estame série I; b6. estame série III; b7. pistilo; b8. fruto. c. O. laxa (Nees) Mez - c1. folha (face abaxial); c2. flor (ふ̋); c3. tépala; c4. estame série I; c5. estame série III; c6. pistilo; c7. fruto. d. O. lobbii (Meisn.) Rohwer - d1. folha (face abaxial); d2. tépala; d3. estame série I; d4. estame série III; d5. pistilo; d6. fruto. e. $O$. nectandrifolia Mez - e1. folha (face abaxial); e2. flor ( đ̊); e3. tépala; e4. estame série I; e5. estame série III; e6. pistilo; e7. fruto. (a1 Hatschbach 23359; a2-a5 Wanderley 122; a6 Cerqueira 22; b1,b2,b8 Brotto 374; b3-b6 Hatschbach 9082; b7 Ferreira 28; c1-c3,c6 Koczicki MBM 12134; c4-c5 Silva 52; c7 Forzza 4241; d1-d5 Hatschbach 12743 ; d6 Canha UPCB 41743; e1-e5 Klein 1158; e6 Brotto 411; e7 Jarenkow 2165).

Figure 3 - a. Ocotea lanata (Nees \& Mart.) Mez - a1. leaf (abaxial surface); a2. tepal; a3. stamen series I; a4. stamen series III; a5. pistil; a6. fruit. b. O. lancifolia (Schott) Mez - b1. fruiting branch; b2. leaf (abaxial surface); b3. flower (§); b4. tepal; b5. stamen series I; b6. stamen series III; b7. pistil; b8. fruit. c. O. laxa (Nees) Mez - c1. leaf (abaxial surface); c2. flower ( $)$ ); c3. tepal; c4. stamen series I; c5. stamen series III; c6. pistil; c7. fruit. d. O. lobbii (Meisn.) Rohwer - d1. leaf (abaxial surface); d2. tepal; d3. stamen series I; d4. stamen series III; d5. pistil; d6. fruit. e. O. nectandrifolia Mez - e1. leaf (abaxial surface); e2. flower (ð); e3. tepal; e4. stamen series I; e5. stamen series III; e6. pistil; e7. fruit. (a1 Hatschbach 23359; a2-a5 Wanderley 122; a6 Cerqueira 22; b1,b2,b8 Brotto 374; b3-b6 Hatschbach 9082; b7 Ferreira 28; c1-c3,c6 Koczicki MBM 12134; c4-c5 Silva 52; c7 Forzza 4241; d1-d5 Hatschbach 12743; d6 Canha UPCB 41743; e1-e5 Klein 1158; e6 Brotto 411; e7 Jarenkow 2165). 
pares, ângulo de divergência $25^{\circ}-40^{\circ}$, nervação camptódroma-broquidódroma, domácias nas axilas, cobertas por tricomas alvos. Inflorescências subterminais; tirsóide ca. 2 cm compr., pauciflora, glabrescente. Flores unissexuadas; estaminadas com pedicelo ca. $3 \mathrm{~mm}$ compr.; hipanto inconspícuo, internamente pubérulo; tépalas ca. 2,2 mm compr., ovalado-elípticas, face abaxial glabra, face adaxial glabrescente, papilas inconspícuas no ápice; estames das séries I e II ca. 1,5 mm compr., filetes $1 / 3$ do comprimento das anteras, glabros, anteras ovalado-retangulares, ápice obtuso, glabras, locelos introrsos; estames da série III ca. 1,5 mm compr., filetes mais curtos que as anteras, glabros, anteras retangulares, ápice truncado, locelos superiores lateral-introrsos e inferiores lateral-extrorsos; estaminódios da série IV ca. $0,8 \mathrm{~mm}$ compr., filiformes; pistiloide estipiforme, pubérulo; pistiladas com estaminódios ca. 0,7 mm compr., pistilo ca. 1,4 mm compr., glabro, ovário globoso, estilete muito curto, estigma lobado. Cúpulas 1,5 $\times 0,9 \mathrm{~cm}$, trompetiformes, margem hexalobada. Frutos $1 \times 0,8 \mathrm{~cm}$, elipsoides.

Material selecionado: Bocaiúva do Sul, 17.IX.1969, fl. (P), C. Koczicki s.n. (MBM 12134). Cerro Azul, 9.VIII.1966, J.C. Lindeman \& J.H. Haas 2146 (MBM). Londrina, 18.V.1985, f1., E.G. Gaudens (FUEL 1121). Sapopema, 6.V.1990, fr., E. Bianchini et al. (FUEL 12540). Telêmaco Borba, 28.IX.1990, fl., S.M. Silva et al. (FUEL 12404).

Material adicional: BRASIL. MINAS GERAIS: Lima Duarte, 19.IX.2006, fr., R.C. Forzza et al. 4241 (RB). Maria da Fé, 23.X.1989, fl. (ठ̊), R.M. Silva et al. 52 (MBM).

No Paraná Ocotea laxa é encontrada na FOD Submontana e Montana, FOM e FES, entre 425 e $800 \mathrm{~m}$, ocupando o dossel. A espécie é rara no estado, embora sua ocorrência em São Paulo e Santa Catarina sugira uma ampla distribuição no Centro-Leste do Paraná, por isso é categorizada nos critérios da IUCN (2001) como Quase Ameaçada (NT). Em material vivo a coloração das flores varia de creme a amarelada e os frutos maduros são vinho-escuros com cúpulas vermelhas. Rohwer (1986) considerou $O$. teleiandra sinônima de $O$. laxa, entretanto, O. teleiandra apresenta folhas sem domácias nas axilas das nervuras e frutos maiores com cúpulas de margem simples, características descritas por Mez (1889) e que puderam ser comprovadas. Assemelha-se a O. brachybotrya, mas esta também apresenta folhas sem domácias. Floresce de setembro a dezembro e maio e frutifica de outubro a maio.
14. Ocotea lobbii (Meisn.) Rohwer, Mitt. Inst. Allg. Bot. Hamburg 20: 113. $1986 . \quad$ Fig. 3 d1-d6 Árvores, $20 \mathrm{~m}$ alt.; ramos com crescimento rítmico, angulosos, glabrescentes. Folhas subopostas; pecíolo 0,3-0,5 cm compr., canaliculado, glabrescente; lâmina 3-6×1-2,5 cm, elíptica ou obovada, ápice obtuso ou arredondado, base cuneada, revoluta, face adaxial glabra, lustrosa, reticulação densa, inconspícua, nervura primária plana a subsaliente, secundárias planas, face abaxial glabra, reticulação densa, nervuras planas, secundárias 7-10 pares, ângulo de divergência $50^{\circ}-80^{\circ}$, nervação broquidódroma, domácias ausentes. Inflorescências subterminais, agrupadas ao redor da gema apical; botrióide 2-6 cm compr., pauciflora, aureo-pubérula. Flores bissexuadas; pedicelo 2-3 mm compr.; hipanto conspícuo, internamente tomentoso; tépalas ca. 2,6 mm compr., elípticas, reflexas, face abaxial pubérula, face adaxial papilosa, papilas na margem; estames das séries I e II ca. 1,4 mm compr., filetes tão longos quanto as anteras, tomentosos, anteras ovaladas, ápice obtuso, papilosas, locelos superiores introrsos e inferiores lateral-introrsos; estames da série III ca. 1,4 mm compr., filetes tão longos quanto as anteras, tomentosos, anteras retangulares, ápice truncado, locelos superiores laterais e inferiores lateral-extrorsos; estaminódios da série IV ca. 0,7 mm compr., clavados, tomentosos; pistilo ca. $2 \mathrm{~mm}$ compr., glabro, ovário elipsoide, estilete tão longo quanto o ovário, estigma capitado, glabrescente. Cúpulas $1 \times 1 \mathrm{~cm}$, sub-hemisféricas, margem dupla. Frutos $1 \times 0,7 \mathrm{~cm}$, elipsoides.

Material selecionado: Paranaguá, 29.I.1996, est., S.M. Silva et al. (UPCB 32146). Pontal do Paraná, 9.VIII.1965, fl., G.G. Hatschbach 12743 (MBM, RB).

Material adicional: BRASIL. SANTA CATARINA: Bombinhas, 2.IX.2005, fl., M.G. Caxambu 908 (MBM). Itapoá, 1.V.1999, fl. e fr., A.M. Canha s.n. (UPCB 41743).

No Paraná Ocotea lobbii é encontrada na FOD das Terras Baixas, entre 3 a 10 m, ocupando o dossel. A espécie é rara no estado, embora sua ocorrência em São Paulo e Santa Catarina sugira uma ampla distribuição no Leste do Paraná, por isso é categorizada nos critérios da IUCN (2001) como Em Perigo (EN B1ab(iii)). Em material vivo a coloração das flores é creme e os frutos maduros são roxos. Baitello (2003) cita a espécie para a Floresta Estacional Semidecidual, formações campestres e floresta de restinga, enquanto Assis (2009) cita $O$. lobbii apenas para formação de restinga, considerando Ocotea virgultosa (Mart. ex Nees) Mez como espécie próxima à $O$. lobbii. 
Segundo este autor, $O$. virgultosa tem cúpula de margem simples e o tipo é proveniente de Minas Gerais, assim como descrito por Mez (1889), enquanto que o tipo de $O$. lobbii com flores teria sido coletado no Rio de Janeiro, embora Meissner (1864) tenha indicado apenas 'In Brasilia merid.' . Levando em consideração que a coleta de Canha (UPCB 41743) apresenta cúpula de margem dupla e pela similaridade da coleta de Hatschbach 12743 com o holótipo confirmado por Rohwer (1986), coleta de Lobb 30 (K, NY), optou-se por aceitar o conceito de Assis (2009). Vegetativamente, pode ser confundida com Ocotea pulchella (Nees \& Mart.) Mez pelo tamanho e forma das folhas, mas a disposição das folhas nesta é alterna e em $O$. lobbii é suboposta. Floresce de maio a setembro e frutifica em maio.

15. Ocotea marumbiensis Brotto \& Baitello, Rodriguésia 63(3): 579-585. 2012. Fig. 1 Rodriguésia 63(3): Pp.581. 2012.

Árvores, $10 \mathrm{~m}$ alt.; ramos com crescimento rítmico, cilíndricos, glabrescentes. Folhas agrupadas no ápice dos ramos e alternas na base; pecíolo 0,3-0,7 cm compr., subcanaliculado, glabro; lâmina 4-9 × 1-3 cm, elíptica, ápice agudo ou acuminado, base cuneada, revoluta, margem ondulada, face adaxial glabra, lustrosa, reticulação densa, nervura primária subsaliente, secundárias planas, face abaxial glabra, reticulação densa, nervura primária saliente, secundárias planas, 8-11 pares, ângulo de divergência $30^{\circ}-65^{\circ}$, nervação broquidódroma, domácias nas axilas basais, podendo faltar em algumas folhas, cobertas por tricomas alvos. Inflorescências subterminais, agrupadas ao redor da gema apical pubérula, subtendidas por brácteas; botrióide a tirsóide $3-5 \mathrm{~cm}$ compr., pauciflora, glabra. Flores bissexuadas; pedicelo ca. $3 \mathrm{~mm}$ compr.; hipanto inconspícuo, internamente pubérulo; tépalas 1,9-2,3 mm compr., ovalado-elípticas, face abaxial glabra, face adaxial glabrescente, papilas na margem; estames das séries I e II 1-1,6 mm compr., filetes um pouco mais curtos que as anteras, pubérulos, anteras ovalado-quadrangulares, ápice agudo, papilosas, locelos introrsos; estames da série III 1,2-1,7 mm compr., filetes tão longos quanto as anteras, pubérulos, anteras retangulares, ápice truncado, locelos superiores laterais e inferiores lateral-extrorsos; estaminódios da série IV ca. 0,6 $\mathrm{mm}$ compr., filiformes, pubérulos; pistilo 2-2,5 mm compr., glabro, ovário elipsoide, estilete tão longo quanto o ovário, estigma subcapitado. Cúpulas ca.
$0,7 \times 0,7 \mathrm{~cm}$, trompetiformes a sub-hemisféricas, margem hexalobada quando jovem ou inteira quando plenamente desenvolvida. Frutos ca. $1 \times$ $0,7 \mathrm{~cm}$, elipsoides, ápice mucronado.

Material selecionado: Morretes, 7.V.2010, fl. e fr., M.L. Brotto \& W.S. Mancineli 447 (MBM, NY, RB, SP, SPSF, UPCB). São José dos Pinhais, 3.VII.1970, fl., G. G. Hatschbach 18144 (MBM). Tijucas do Sul, 6.XI.1998, fr., E. Barbosa et al. 205 (MBM).

No Paraná Ocotea marumbiensis é encontrada na FOD Montana, entre 700 e 1230 m, ocupando o dossel. A espécie é rara no Leste do estado, por isso é categorizada nos critérios da IUCN (2001) como Em Perigo (EN B1ab(iii)). Em material vivo a coloração das flores é esverdeada e os frutos maduros são pretos. Vegetativamente pode ser confundida com $O$. indecora e $O$. prolifera, das quais é diferenciada com segurança por caracteres de folhas, flores e frutos. Ocotea marumbiensis apresenta tépalas ovalado-elípticas e cúpulas trompetiformes a sub-hemisféricas e frutos com até $1 \mathrm{~cm}$ de comprimento, enquanto que $O$. indecora e $O$. prolifera apresentam tépalas estreito-elípticas, cúpulas tipicamente hemisféricas e frutos com até 2 $\mathrm{cm}$ de comprimento. Coletada com flores de janeiro a outubro e com frutos de maio a novembro.

16. Ocotea nectandrifolia Mez, Arbeiten Königl. Bot. Gart. Breslau 1: 122. $1892 . \quad$ Fig. 3e1-e7

Árvores, $25 \mathrm{~m}$ alt.; ramos subcilíndricos, ferrugíneo-tomentosos. Folhas alternas; pecíolo 0,9-1,5 cm compr., subcanaliculado, tomentoso; lâmina 5,5-11 × 2-4 cm, discolor, elíptica ou ovada, ápice acuminado, base cuneada ou obtusa, revoluta, face adaxial glabrescente, tomentosa sobre as nervuras, reticulação densa, nervuras planas, face abaxial ferrugíneo-tomentosa, reticulação densa, nervuras salientes, secundárias 4-7 pares, ângulo de divergência $25^{\circ}-50^{\circ}$, nervação broquidódroma, domácias nas axilas basais, cobertas por tricomas ferrugíneos. Inflorescências axilares e subterminais; botrióide $2-10 \mathrm{~cm}$ compr., multiflora, ferrugíneo-tomentosa. Flores unissexuadas; estaminadas com pedicelo ca. 1,5 mm compr.; hipanto conspícuo, internamente tomentoso; tépalas 2,4-3 $\mathrm{mm}$ compr., elípticas, tomentosas em ambas as faces, papilas inconspícuas na margem e no ápice; estames das séries I e II ca. $1,7 \mathrm{~mm}$ compr., filetes tão longos quanto as anteras, tomentosos, anteras ovalado-quadrangulares, ápice obtuso, glabras, locelos introrsos; estames da série III ca. 2,6 mm compr., filetes tão longos quanto as 
anteras, tomentosos, anteras retangulares, ápice truncado, locelos superiores lateral-introrsos e inferiores laterais; estaminódios da série IV ca. 1,7 mm compr., filiformes, tomentosos; pistiloide ausente; pistiladas com estaminódios ca. $1 \mathrm{~mm}$ compr., pistilo ca. $2 \mathrm{~mm}$ compr., glabro, ovário globoso, estilete curto, estigma lobado. Cúpulas 1 $\times 1,2 \mathrm{~cm}$, hemisféricas, margem hexalobada. Frutos $1,6 \times 1,2 \mathrm{~cm}$, ovalados ou elipsoides.

Material selecionado: Cerro Azul, 16.XII.1992, fl., G.G. Hatschbach \& O.S. Ribas 58456 (MBM). Colombo, 23.IV.1980, fr., E. Rotta 170 (HFC, HFIE, HUEM, SPSF). Guaraqueçaba, 26.IV.1985, fr., Y.S. Kuniyoshi 6027

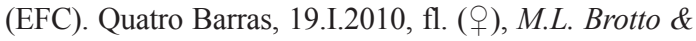
R. Franzen Jr. 411 (FUEL, MBM, NY, RB, SPSF, UPCB). Material adicional: BRASIL. SANTA CATARINA: Itajaí, 10.II.1955, fl. (ठ̊), R. Klein 1158 (MBM). RIO GRANDE DO SUL: Torres, 29.X.1992, fr., J.A. Jarenkow \& R. Záchia 2165 (MBM).

No Paraná Ocotea nectandrifolia é encontrada na FOD Submontana, Montana e FOM, entre 400 e $1.100 \mathrm{~m}$, ocupando o dossel. A espécie é amplamente distribuída no Leste do Paraná, sendo frequente na FOD e rara na FOM, por isso é categorizada nos critérios da IUCN (2001) como Quase Ameaçada (NT). Em material vivo a coloração da flor varia de creme a esverdeada, exalando odor suave. Rohwer (1986) sinonimizou $O$. nectandrifolia em Ocotea urbaniana Mez, entretanto, esta é uma espécie com flores bissexuadas. Além disso, as folhas estreito-elípticas de $O$. urbaniana diferem das elípticas ou ovadas de $O$. nectandrifolia. Por isso se aceita o conceito de Mez (1889) e descarta-se aqui a sinonimização feita por Rohwer (1986). Das espécies dióicas é a única com folhas discolores ferrugíneo-tomentosas na face abaxial. Floresce de dezembro a fevereiro e frutifica de março a outubro.

17. Ocotea notata (Nees \& Mart.) Mez, Jahrb. Königl. Bot. Gart. Berlin 5: 339. 1889.

Fig. 4a1-a7

Árvores, $10 \mathrm{~m}$ alt.; ramos cilíndricos, não lustrosos, glabros. Folhas alternas; pecíolo $1-2 \mathrm{~cm}$ compr., achatado, glabro; lâmina 5,5-13 × 2,5-5 $\mathrm{cm}$, ovada ou ovado-elíptica, ápice acuminado, base atenuada, face adaxial glabra, reticulação densa, nervura primária subsaliente, secundárias planas, face abaxial glabra, reticulação densa, nervuras planas, secundárias 5-7 pares, ângulo de divergência $40^{\circ}-60^{\circ}$, nervação camptódroma-broquidódroma, domácias ausentes. Inflorescências axilares ou subterminais; tirsóide 3-6 cm compr., pauciflora ou multiflora, glabra. Flores unissexuadas; estaminadas com pedicelo 2-3 mm compr.; hipanto inconspícuo, internamente pubérulo; tépalas 2-2,3 mm compr., ovalado-elípticas, face abaxial glabra, face adaxial glabrescente; estames das séries I e II 1,4-1,6 mm compr., filetes pouco mais curtos que as anteras, glabros, anteras ovalado-retangulares, ápice obtuso, glabras, locelos introrsos; estames da série III 1,4-1,7 mm compr., filetes pouco mais curtos que as anteras, glabros, anteras retangulares, ápice truncado, locelos laterais; estaminódios da série IV inconspícuos ou ausentes; pistiloide filiforme, glabro; pistiladas com estaminódios ca. 0,7 mm compr.; pistilo ca. 1,3 mm compr., glabro, ovário globoso, estilete curto, espesso, estigma discóide. Cúpulas 0,6 × 0,6 cm, sub-hemisféricas, margem simples. Frutos $0,9 \times 0,6 \mathrm{~cm}$, elipsoides. Material selecionado: Bocaiúva do Sul, 23.I.1963, fl. (P), G. G. Hatschbach 9879 (MBM). Tunas do Paraná, 20.XII.1960, fl. (ð), G.G. Hatschbach 7597 (MBM). Material adicional: BRASIL. RIO DE JANEIRO: Rio de Janeiro, 27.VI.1961, fr., A.P. Duarte 5875 (RB).

No Paraná Ocotea notata é encontrada na FOD Montana, a cerca de $900 \mathrm{~m}$, ocupando o sub-bosque. A espécie é rara no Paraná, entretanto, essa raridade pode estar relacionada com seu limite austral de ocorrência, a região limítrofe entre o Leste do Paraná e Sudeste de São Paulo, por isso é categorizada nos critérios da IUCN (2001) como Em Perigo (EN B1ab(iii)). Em material vivo a coloração das flores varia de creme a amarelada. Sua principal característica são os pecíolos achatados. Floresce de dezembro a janeiro e frutifica de junho a agosto.

18. Ocotea nunesiana (Vattimo-Gil) Baitello, Fl. Fanerog. Estado São Paulo 3: 198. 2003.

Fig. 4b1-b7

Árvores, $12 \mathrm{~m}$ alt.; ramos fortemente angulosos, aureo-pubérulos. Folhas alternas; pecíolo 1-2,5 cm compr., canaliculado, pubérulo; lâmina 6-18 × 2-6 cm, elíptica ou obovada, ápice agudo, base cuneada, não revoluta, face adaxial glabra, reticulação laxa, nervuras planas, face abaxial glabrescente, reticulação laxa, nervuras salientes, secundárias 6-9 pares, ângulo de divergência $30^{\circ}-45^{\circ}$, nervação broquidódroma, domácias ausentes. Inflorescências axilares e subterminais, agrupadas ao redor da gema apical; tirsóide 4-19 cm compr., multiflora, aureopubérula. Flores bissexuadas; pedicelo ca. 2 $\mathrm{mm}$ compr.; hipanto inconspícuo, internamente tomentoso; tépalas ca. 3,5 $\mathrm{mm}$ compr., estreitoelípticas, face abaxial pubérula, face adaxial tomentosa, papilas na margem; estames das 

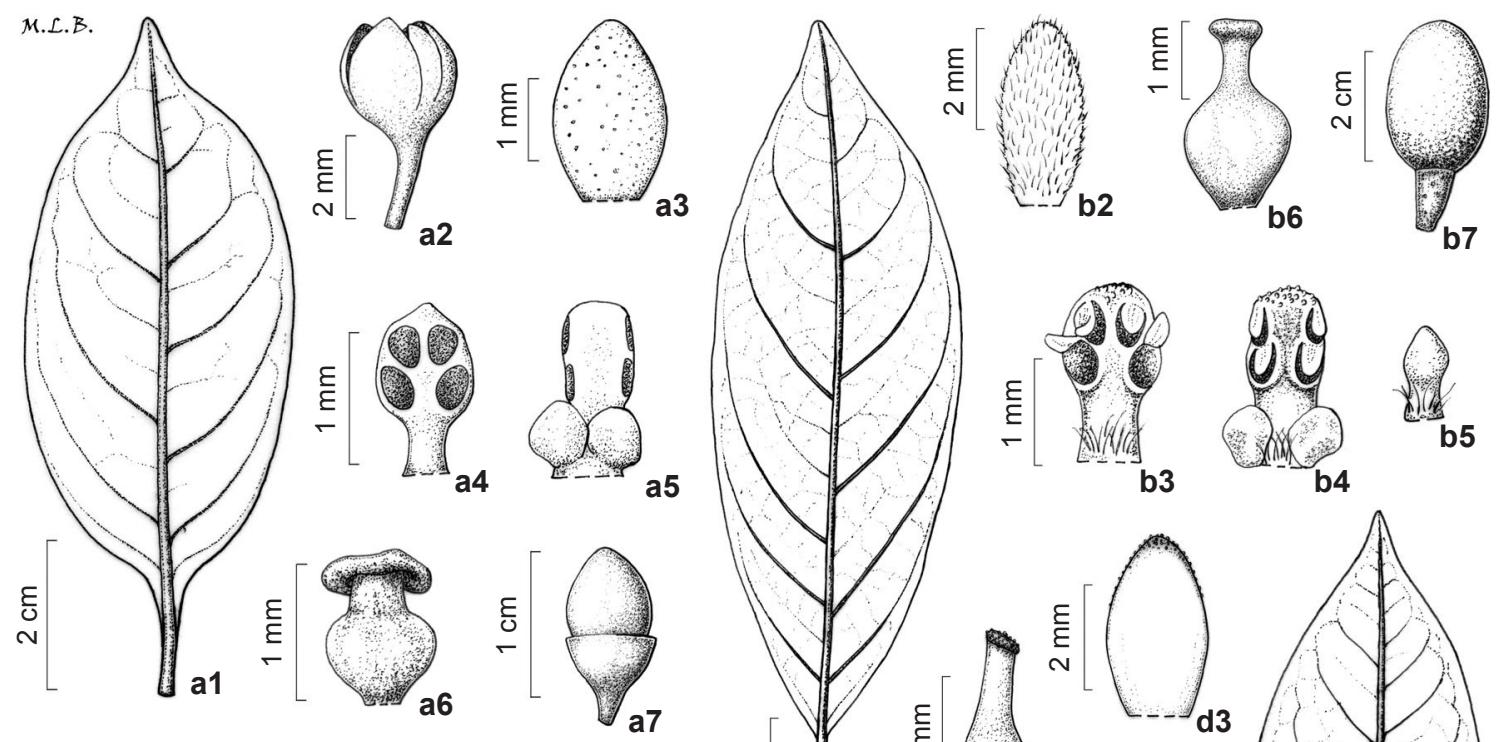

7
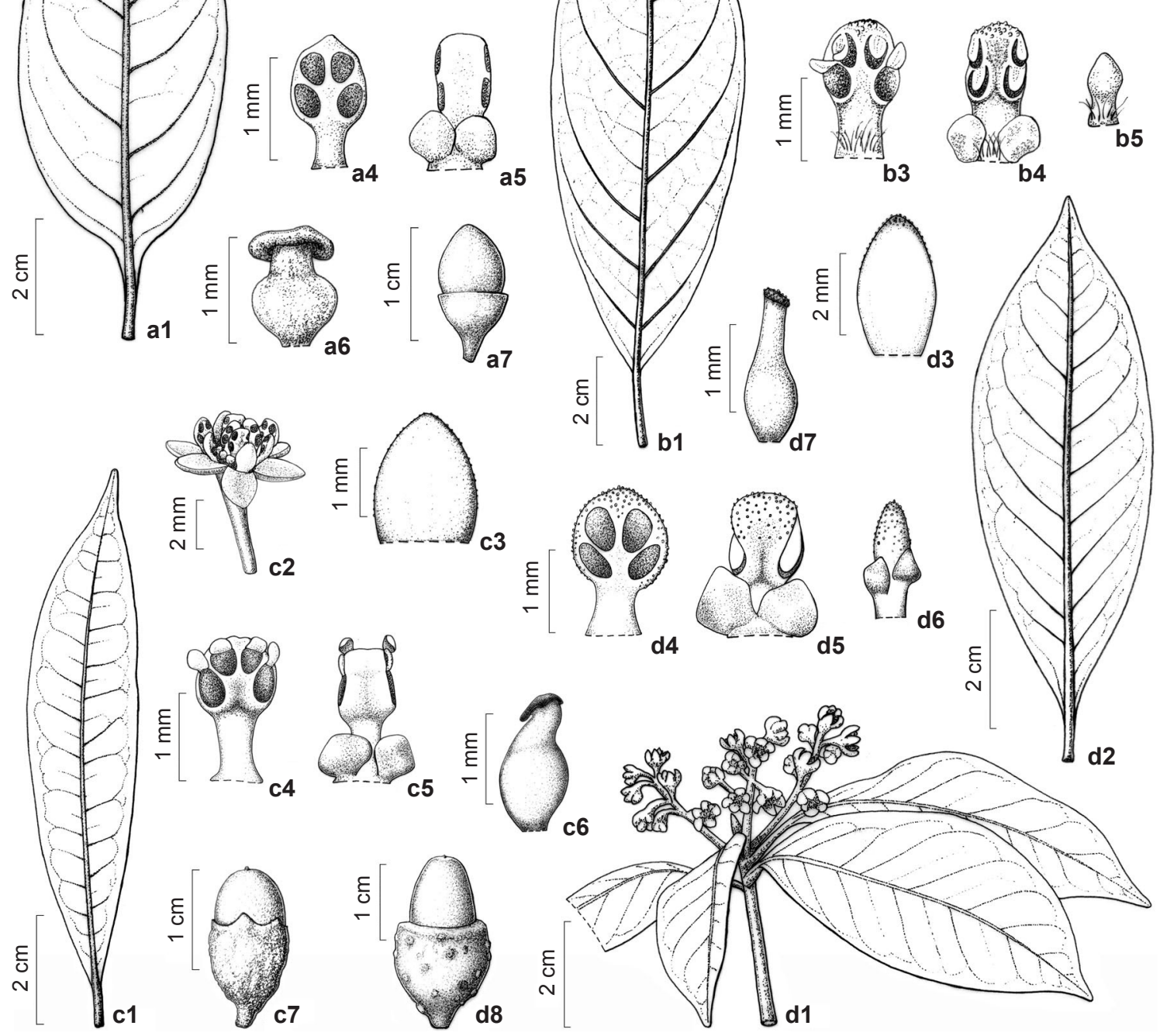

Figura 4 - a. Ocotea notata (Nees \& Mart.) Mez - a1. folha (face abaxial); a2. flor (ð̋); a3. tépala; a4. estame série I; a5. estame série III; a6. pistilo; a7. fruto. b. O. nunesiana (Vattimo-Gil) Baitello - b1. folha (face abaxial); b2. tépala; b3. estame série I; b4. estame série III; b5. estaminódio série IV; b6. pistilo; b7. fruto. c. O. nutans (Nees) Mez - c1. folha (face abaxial); c2. flor ( 0 ); c3. tépala; c4. estame série I; c5. estame série III; c6. pistilo; c7. fruto. d. O. odorifera (Vell.) Rohwer-d1. ramo com flores; d2. folha (face abaxial); d3. tépala; d4. estame série I; d5. estame série III; d6. estaminódio série IV; d7. pistilo; d8. fruto. (a1-a5 Hatschbach 7597; a6 Hatschbach 9879; a7 Duarte 5875; b1,b7 Brotto 363; b2-b6 Santos 1055; c1-c5 Brotto 77; c6 Tramujas 96; c7 Gatti 331; d1-d7 Brotto 284; d8 Brotto 621). Figure 4 - a. Ocotea notata (Nees \& Mart.) Mez - a1. leaf (abaxial surface); a2. flower ( $\left.{ }^{\prime}\right)$; a3. tepal; a4. stamen series I; a5. stamen series III; a6. pistil; a7. fruit. b. O. nunesiana (Vattimo-Gil) Baitello - b1. leaf (abaxial surface); b2. tepal; b3. stamen series I; b4. stamen series III; b5. staminode series IV; b6. pistil; b7. fruit. c. O. nutans (Nees) Mez - c1. leaf (abaxial surface); c2. flower (ô); c3. tepal; c4. stamen series I; c5. stamen series III; c6. pistil; c7. fruit. d. O. odorifera (Vell.) Rohwer-d1. flowering branch; d2. leaf (abaxial surface); d3. tepal; d4. stamen series I; d5. stamen series III; d6. staminode series IV; d7. pistil; d8. fruit. (a1-a5 Hatschbach 7597; a6 Hatschbach 9879; a7 Duarte 5875; b1,b7 Brotto 363; b2-b6 Santos 1055; c1-c5 Brotto 77; c6 Tramujas 96; c7 Gatti 331; d1-d7 Brotto 284; d8 Brotto 621). 
séries I e II ca. 1,6 mm compr., filetes tão longos quanto as anteras, glabrescentes, anteras ovaladoquadrangulares, ápice obtuso, papilosas, locelos introrsos; estames da série III ca. 1,6 mm compr., filetes tão longos quanto as anteras, glabrescentes, anteras retangulares, papilosas no ápice truncado, locelos lateral-extrorsos; estaminódios da série IV ca. $0,8 \mathrm{~mm}$ compr., clavados, pubérulos; pistilo ca. 2,3 mm compr., glabro, ovário globoso-elipsoide, estilete curto, estigma subcapitado. Cúpulas 1,5 $\times$ $0,9 \mathrm{~cm}$, infundibuliformes, margem simples. Frutos $2,5 \times 1,3 \mathrm{~cm}$, elipsoides.

Material selecionado: Colombo, 18.VIII.1995, fl., W. Maschio 74 (HFC, MBM, SPSF). Guaraqueçaba, 9.VIII.1967, fr., G.G. Hatschbach 16888 (MBM). Guaratuba, 10.X.2001, fl. e fr., E.P. Santos et al. 1055 (SPSF, UPCB). Morretes, 12.VII.2009, fr., M.L. Brotto 363 (FUEL, MBM, NY, RB, SPSF, UPCB). Quatro Barras, 21.IX.2009, fl., M.L. Brotto 378 (MBM, NY, RB, SPSF, UPCB).

No Paraná Ocotea nunesiana é encontrada na FOD Submontana e Montana e na FOM, entre 50 a $1.100 \mathrm{~m}$, ocupando o dossel. A espécie é amplamente distribuída no Leste do Paraná, sendo frequente na FOD e rara na FOM, por isso é categorizada nos critérios da IUCN (2001) como Quase Ameaçada (NT). Prefere florestas secundárias em estágio inicial e médio de sucessão, mas também ocorre em florestas primárias. Vegetativamente pode ser confundida com Nectandra membranacea (Sw.) Griseb. pelo tamanho e forma das folhas. Em material vivo a coloração das flores varia entre creme, amarelada e verde, os frutos imaturos são brancos e os maduros brancoesvedeados, sendo essa uma característica rara dentro do grupo. Os ramos fortemente angulosos também são uma característica dessa espécie. Floresce de agosto a dezembro e frutifica de outubro a agosto.

19. Ocotea nutans (Nees) Mez, Jahrb. Königl. Bot. Gart. Berlin 5: 362. 1889.

Fig. 4c1-c7

Árvores, $30 \mathrm{~m}$ alt.; ramos cilíndricos, lustrosos, glabros. Folhas alternas; pecíolo $0,3-0,6$ $\mathrm{cm}$ compr., ca. $0,1 \mathrm{~cm}$ espessura, canaliculado, glabro; lâmina 5-12 × 1-3 cm, lanceolada, ápice agudo, base cuneada, face adaxial glabra, reticulação densa, nervura primária subsaliente, secundárias planas, face abaxial glabra, reticulação densa, nervura primária saliente, secundárias planas, $8-12$ pares, ângulo de divergência $40^{\circ}-65^{\circ}$, nervação broquidódroma, domácias ausentes. Inflorescências axilares e subterminais; tirsóide 3-6 cm compr., multiflora, glabra. Flores unissexuadas; estaminadas com pedicelo 2-3 mm compr.; hipanto inconspícuo, internamente glabro; tépalas 1,8-2,2 mm compr., ovalado-elípticas, glabras em ambas as faces, papilas incospícuas na margem; estames das séries I e II 1,5-1,7 mm compr., filetes tão longos quanto as anteras, glabros, anteras ovaladas, ápice obtuso, glabras, locelos superiores introrsos e inferiores lateral-introrsos; estames da série III ca. 1,6 mm compr., filetes tão longos quanto as anteras, glabros, anteras retangulares, ápice truncado, locelos superiores lateral-introrsos e inferiores lateral-extrorsos; estaminódios da série IV ausentes; pistiloide filiforme; pistiladas com estaminódios ca. $0,5 \mathrm{~mm}$ compr.; pistilo ca. 1,5 $\mathrm{mm}$ compr., glabro, ovário elipsoide, estilete curto, estigma subcapitado. Cúpulas ca. $1 \times 1 \mathrm{~cm}$, trompetiformes, margem hexalobada. Frutos ca. 1,1 $\times 0,9 \mathrm{~cm}$, elipsoides, ápice mucronado.

Material selecionado: Araucária, 14.XI.1998, fr., G. Gatti \& A.L.S. Gatti 331 (MBM, UPCB). Colombo, 19.VI.1990, f1. ()), A.P. Tramujas 96 (EFC, SPSF). Curitiba, 15.III.2008, fl. (đ), M.L. Brotto 77 (MBM, UPCB). Piên, 6.X.1987, fr., G.G. Hatschbach \& J.M. Silva 51483 (MBM, SPSF). Quatro Barras, 7.V.2011, fl., M.L. Brotto 658 (MBM, UPCB).

No Paraná Ocotea nutans é encontrada na FOM, entre 800 a 970 m, ocupando o dossel. A espécie é frequente e amplamente distribuída no primeiro e segundo planaltos do Paraná, sendo categorizada nos critérios da IUCN (2001) como Menor Preocupação (LC). Em material vivo a coloração das flores é creme e os frutos maduros são pretos com cúpulas vermelhas. Entre as espécies com flores unissexuadas é a única com ramos lustrosos. Floresce de fevereiro a junho, com pico entre março e abril, e frutifica de maio a janeiro.

20.Ocotea odorifera (Vell.) Rohwer, Mitt. Inst. Allg. Bot. Hamburg 20: 111. $1986 . \quad$ Fig. 4d1-d8 Árvores, $15 \mathrm{~m}$ alt.; ramos com crescimento rítmico, angulosos, glabros. Folhas subverticiladas para o ápice dos ramos e alternas na base; pecíolo 0,5-1,5 cm compr., canaliculado, glabro; lâmina $6-15 \times 2-5,5 \mathrm{~cm}$, elíptica, ápice agudo ou acuminado, base cuneada, face adaxial glabra, reticulação densa, nervura primária subsaliente, secundárias planas, face abaxial glabra, reticulação densa, nervuras subsalientes, secundárias 7-13 pares, ângulo de divergência $40^{\circ}-65^{\circ}$, nervação broquidódroma, domácias ausentes. Inflorescências subterminais, agrupadas ao redor da gema apical, subtendidas por brácteas; tirsóide $2-8 \mathrm{~cm}$ compr., pauciflora ou multiflora, glabra. Flores bissexuadas; pedicelo ca. $2 \mathrm{~mm}$ compr.; hipanto conspícuo, internamente pubérulo; tépalas ca. 3 
mm compr., elípticas, glabras em ambas as faces, papilas na margem; estames das séries I e II ca. $1,8 \mathrm{~mm}$ compr., filetes $1 / 2$ do comprimento da antera, glabros, anteras orbiculares, ápice obtuso, papilosas, locelos introrsos; estames da série III ca. $1,8 \mathrm{~mm}$ compr., filetes $1 / 2$ do comprimento da antera, glabros, anteras retangulares, ápice truncado, papilosas, locelos laterais; estaminódios da série IV ca. 1,3 mm compr., liguliformes, glabros; pistilo ca. 2,4 mm compr., glabro, ovário elipsoide, estilete longo, estigma subcapitado. Cúpulas 1,6 × 1,2 cm, hemisféricas, lenticeladas, margem simples. Frutos $2 \times 1 \mathrm{~cm}$, elipsoides.

Material selecionado: Colombo, 1.X.1986, fr., $W$. Maschio 71 (HFC, HUEM, MBM, SPSF). Curitiba, 30.I.2010, fl., M.L. Brotto 414 (MBM, NY, RB, SPSF, UPCB). Jaguariaíva, 17.IV.2011, fr., M.L. Brotto 628 (MBM, RB, SP, UPCB). Morretes, 7.II.2009, fl., M.L. Brotto \& R.C. Dorneles 284 (UPCB). Ponta Grossa, 16.IV.1979, fr., M.L. Brotto et al. 621 (MBM, RB, UPCB).

No Paraná Ocotea odorifera é encontrada na FOD das Terras Baixas, Submontana, Montana, FOM, FES e Savana, entre 10 a 1.000 m, ocupando o dossel. A espécie é amplamente distribuída no estado com exceção do terceiro planalto, sendo frequente na FOD e FOM e rara na FES e Savana. Tem preferência por florestas em estágio avançado de sucessão como pode ser observado no Parque Estadual de Vila Velha, município de Ponta Grossa. Foi intensamente explorada no primeiro e segundo planaltos paranaenses assim como a araucária e a imbuia, justificando sua inclusão na lista brasileira de extinção (MMA 2008). No Paraná, entretanto, é categorizada nos critérios da IUCN (2001) como Menor Preocupação (LC). Em material vivo a coloração das flores varia entre creme, alva e branca, exalando odor suave. A madeira apresenta odor acentuado. As folhas glabras subverticiladas para o ápice dos ramos são a principal característica dessa espécie. Floresce de janeiro a março e frutifica durante o ano todo.

21. Ocotea paranaensis Brotto, Baitello, Cervi \& E.P. Santos, Rodriguésia 61(Sup.): S57-S60. 2010. Fig. 1: Rodriguésia 61(Sup.): S59. 2010.

Árvores, $14 \mathrm{~m}$ alt.; ramos cilíndricos, glabrescentes. Folhas alternas; pecíolo $0,4-1 \mathrm{~cm}$ compr., ca. $0,1 \mathrm{~cm}$ espessura; subcanaliculado, tomentoso; lâmina 4-8 $\times 1-2 \mathrm{~cm}$, estreito-elíptica ou lanceolada, ápice acuminado, base cuneada, revoluta, face adaxial glabra, reticulação densa, inconspícua, nervuras planas, face abaxial glabrescente, reticulação densa, nervuras salientes, secundárias
4-6 pares, ângulo de divergência $20^{\circ}-60^{\circ}$, nervação broquidódroma, domácias ausentes. Inflorescências axilares e subterminais; tirsóide 4-7 cm compr., multiflora, aureo-tomentosa. Flores unissexuadas, tomentosas; estaminadas com pedicelo ca. 2 $\mathrm{mm}$ compr.; hipanto inconspícuo, internamente tomentoso; tépalas 1,9-2,2 $\mathrm{mm}$ compr., elípticas, reflexas, tomentosas em ambas as faces, papilas inconspícuas na margem; estames das séries I e II ca. 2,3 mm compr., filetes tão longos quanto as anteras, tomentosos, anteras ovalado-retangulares, ápice obtuso, glabras, locelos introrsos; estames da série III ca. 2,3 mm compr., filetes tão longos quanto as anteras, tomentosos, anteras ovalado-retangulares, ápice obtuso, locelos superiores lateral-introrsos e inferiores lateral-extrorsos; estaminódios da série IV ca. 0,7 mm compr., inconspícuos, tomentosos; pistiloide ca. 2,8 mm compr., estipiforme, tomentoso; pistiladas com estaminódios 1,3-1,5 mm compr.; pistilo ca. 3,5 mm compr., tomentoso, ovário globoso, estilete longo, estigma capitado. Cúpulas ca. 0,7 × $0,5 \mathrm{~cm}$, sub-hemisféricas, rasas, margem simples. Frutos ca. 1,5 × 1,5 cm, globosos.

Material selecionado: Guaratuba, 7.V.2007, fl. (\&), E.P. Santos \& M.L. Brotto 1184 (MBM, RB, SPSF, UPCB). São José dos Pinhais, 10.I.2004, fr., A. Dunaiski Jr. 2230 (HFIE, UPCB). Tijucas do Sul, 27.III.1990, fl. (đ) ), J.M. Silva \& G. Hatschbach 838 (ESA, MBM, MO). Tunas do Paraná, 23.III.2001, fl. (ठึ), J.M. Silva et al. 3357 (MBM, MO, RB).

No Paraná Ocotea paranaensis é encontrada na FOD Montana, entre 850 e 975 m, ocupando o dossel. A espécie é rara, embora sua ocorrência entre os municípios de Guaratuba e Tunas do Paraná sugira uma ampla distribuição no Leste do estado, por isso é categorizada nos critérios da IUCN (2001) como Em Perigo (EN B1ab(iii)). Em material vivo, a coloração das flores varia de creme a verde. Vegetativamente pode ser confundida com $O$. pulchella, da qual difere pela ausência de domácias e com $O$. bicolor e $O$. lancifolia, das quais difere pelo menor número de nervuras secundárias. As flores tomentosas e os frutos globosos assentados sobre cúpula de margem simples são as principais características que diferenciam $O$. paranaensis dessas espécies. Floresce de março a maio e frutifica de julho a janeiro.

22. Ocotea porosa (Nees \& Mart.) Barroso, Rodriguésia 24: 140. $1949 . \quad$ Fig. 5a1-a8

Árvores, $20 \mathrm{~m}$ alt.; ramos subcilíndricos, ferrugíneo-glabrescentes. Folhas alternas em todo o ramo; pecíolo $0,3-1 \mathrm{~cm}$ compr., canaliculado, glabrescente; lâmina 3-8 × 1-3,5 cm, obovada ou 
elíptica, ápice agudo ou acuminado, base cuneada, margem ondulada, face adaxial glabrescente, lustrosa, bulada sobre as domácias, reticulação densa, nervura primária subsaliente, secundárias planas, face abaxial glabrescente, reticulação densa, nervuras subsalientes, secundárias 4-7 pares, ângulo de divergência $25^{\circ}-60^{\circ}$, nervação camptódroma-broquidódroma, domácias nas axilas basais, cobertas por tricomas ferrugíneos. Inflorescências axilares; botrióide $2-3 \mathrm{~cm}$ compr., pauciflora, ferrugíneo-pubérula. Flores bissexuadas; pedicelo ca. $2 \mathrm{~mm}$ compr.; hipanto inconspícuo, internamente glabro; tépalas 1,5-2,3 mm compr., ovalado-elípticas, face abaxial pubérula, papilas no ápice e na margem; estames das séries I e II 1,2-1,5 mm compr., filetes tão longos quanto as anteras, glabrescentes, anteras ovalado-quadrangulares, ápice obtuso, papilosas, locelos introrsos; estames da série III ca. 1,4-1,8 mm compr., filetes tão longos quanto as anteras, glabrescentes, anteras retangulares, ápice truncado, papilosas, locelos superiores laterais e inferiores lateral-extrorsos; estaminódios da série IV 0,6-1,1 mm compr., clavados, pubérulos; pistilo 1,7-2,4 mm compr., glabro, ovário elipsoide, estilete longo, estigma subcapitado. Cúpulas $0,9 \times 0,9 \mathrm{~cm}$, sub-hemisféricas a quase planas, margem simples. Frutos 1,2 × 1,1 cm, globosos.

Material selecionado: Campina Grande do Sul, 5.IV.2008, fl., M.L. Brotto et al. 114 (NY, UPCB). Clevelândia, 5.III.1991, fr., J.M. Silva \& S.D.P. Kricum 938 (MBM, UPCB). Curitiba, 15.III.2008, fr., M.L. Brotto 79 (UPCB). Guaratuba, 22.IX.2006, fr., M. L. Brotto 3 (MBM, RB, UPCB). Palmeira, 22.X.1965, fl., G.G. Hatschbach 13040 (MBM, RB, UPCB).

No Paraná Ocotea porosa é encontrada na FOD Montana, Altomontana, FOM e FES, entre 620 e $1.650 \mathrm{~m}$, ocupando o dossel. A espécie é amplamente distribuída no estado em altitudes superiores a 850 m sendo frequente na FOD e FOM e rara na FES. Está entre as espécies mais representativas na FOD Altomontana. É abundante em florestas primárias e apresenta boa regeneração em florestas secundárias. Foi intensamente explorada no primeiro e segundo planaltos paranaenses, justificando sua inclusão na lista brasileira de extinção (MMA 2008). No Paraná, entretanto, é categorizada nos critérios da IUCN (2001) como Menor Preocupação (LC). Em material vivo a coloração das flores varia de branca a creme e os frutos maduros são pretos. A madeira apresenta odor acentuado. A espécie quando coletada na FOM apresenta folhas lanceoladas diferindo das folhas obovadas ou elípticas quando coletada na FOD. Vegetativamente pode ser confundida com $O$. catharinensis e $O$. indecora diferindo pelas domácias cobertas por tricomas ferrugíneos. Floresce de agosto a janeiro na FOM e de janeiro a abril na FOD, frutifica de outubro a abril na FOM e de março a outubro na FOD.

23. Ocotea prolifera (Nees \& Mart.) Mez, Jahrb. Königl. Bot. Gart. Berlin 5: 250. 1889.

Fig. 5b1-b6

Árvores, $20 \mathrm{~m}$ alt.; ramos com crescimento rítmico, subcilíndricos, glabros. Folhas subopostas para o ápice dos ramos e alternas na base; pecíolo 0,5-1 cm compr., canaliculado, glabro; lâmina 5-15 $\times 1,5-4,5 \mathrm{~cm}$, elíptica, ápice agudo ou acuminado, base cuneada, margem ondulada, face adaxial glabra, lustrosa, reticulação densa, nervura primária imersa, secundárias planas, face abaxial glabra, reticulação densa, nervura primária saliente, secundárias planas, 8-10 pares, ângulo de divergência $30^{\circ}-70^{\circ}$, nervação broquidódroma, domácias ausentes. Inflorescências subterminais, agrupadas ao redor da gema apical glabra, subtendidas por brácteas; tirsóide 2-10 cm compr., multiflora, glabra. Flores bissexuadas; pedicelo ca. $2 \mathrm{~mm}$ compr.; hipanto conspícuo, internamente pubérulo; tépalas ca. 2,5 mm compr., estreito-elípticas, glabra em ambas as faces, papilas na margem; estames das séries I e II 1,3-1,5 mm compr., filetes um pouco mais curtos que as anteras, glabros, anteras orbiculares, ápice obtuso, papilosas, locelos introrsos; estames da série III ca. 1,5 mm compr., filetes tão longos quanto as anteras, glabros, anteras quadrangulares, ápice truncado, locelos superiores laterais e inferiores lateral-extrorsos; estaminódios da série IV 0,7-0,9 mm compr., filiformes, pubérulos; pistilo ca. $2 \mathrm{~mm}$ compr., glabro, ovário elipsoide, estilete igual ou pouco mais curto que o ovário, estigma subcapitado. Cúpulas ca. 1,8 × 1,4 cm, hemisféricas, lenticeladas, margem simples. Frutos ca. $2 \times 1,3 \mathrm{~cm}$, elipsoides. Material selecionado: Cerro Azul, 6.I.1982, fl., R.L. Landrum 4086 (MBM). Diamante do Norte, 29.V.2011, fr., M.L. Brotto 712 (MBM, NY, RB, SP, UPCB). Ibiporã, 2.III.1995, fl., M.C. Dias \& V.F. Mansano (FUEL 17577, RB 361755, UPCB 44120). Londrina, 17.II.1989, fl., L.H. Soares e Silva 189 (FUEL, UPCB). Rancho Alegre, 12.XII.1997, fr., L.R.M. Souza et al. (FUEL 21279, HUPG 7299, MBM 230767, SPSF 9277).

Material adicional: BRASIL. SÃO PAULO: Teodoro Sampaio, 26.II.1986, fr., J.A. Pastore 155 (SPSF).

No Paraná Ocotea prolifera é encontrada na FES no norte do estado e na FOD Submontana no alto vale do rio Ribeira, entre 350 e 600 m, ocupando o dossel. A espécie é rara no estado, com provável 

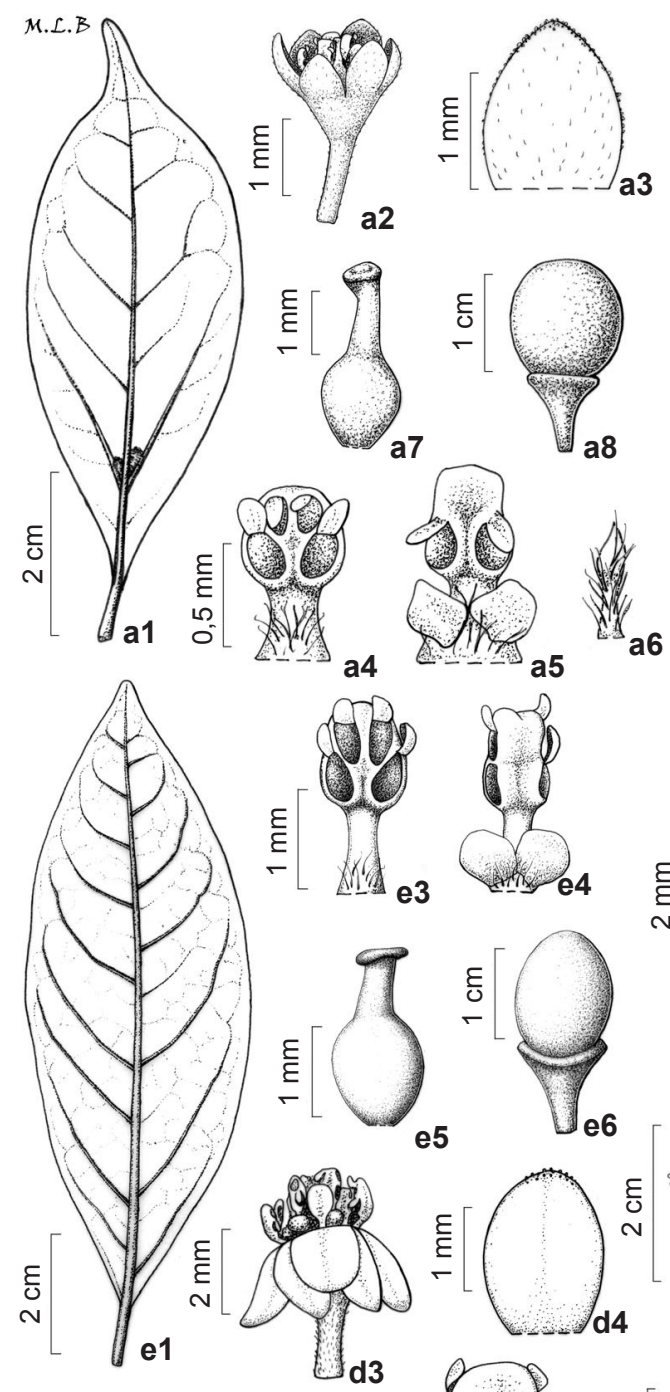

a6
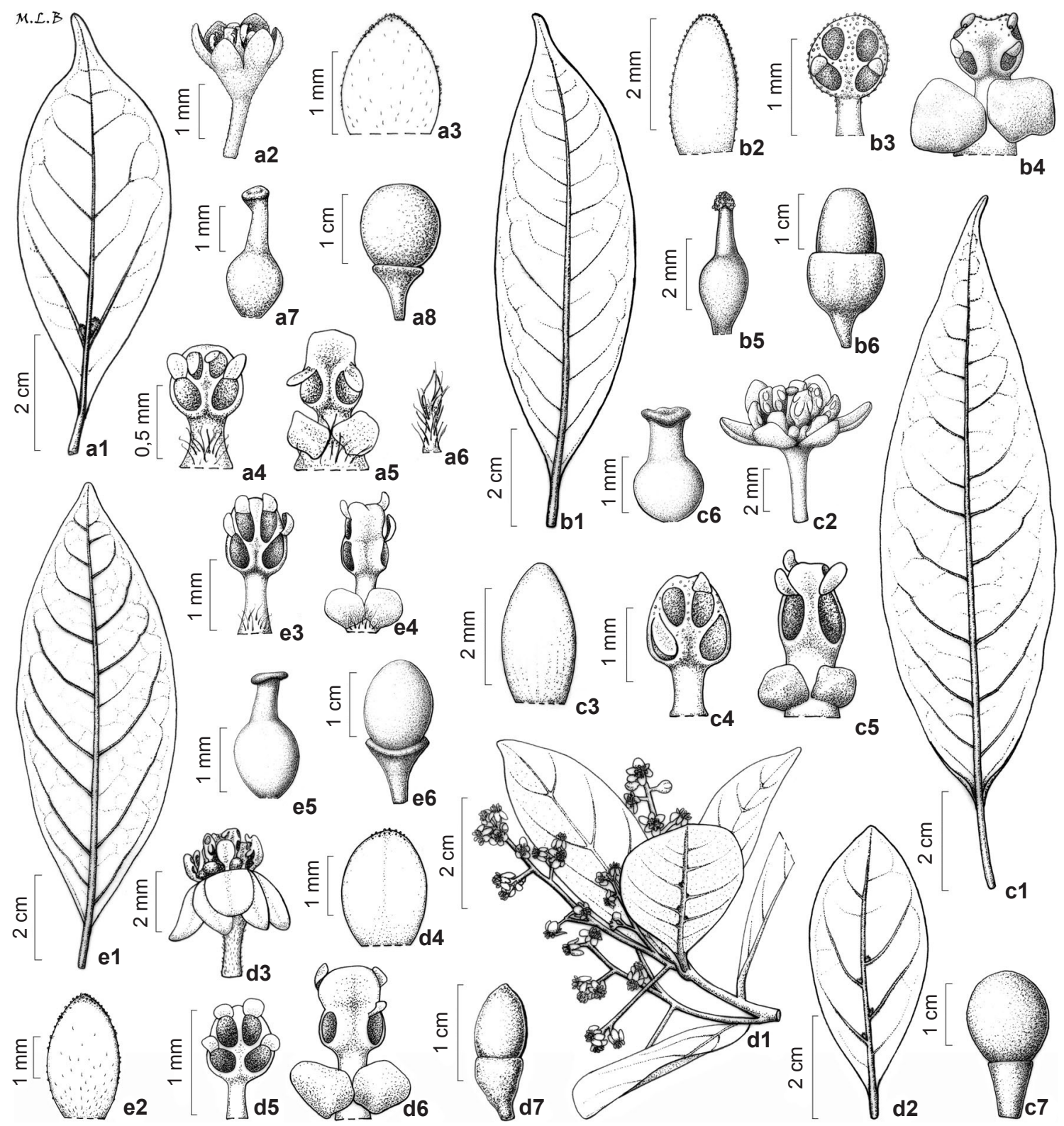

Figura 5 - a. Ocotea porosa (Nees \& Mart.) Barroso - a1. folha (face abaxial); a2. flor; a3. tépala; a4. estame série I; a5. estame série III; a6. estaminódio série IV; a7. pistilo; a8. fruto. b. O. prolifera (Nees \& Mart.) Mez - b1. folha (face abaxial); b2. tépala; b3. estame série I; b4. estame série III; b5. pistilo; b6. fruto. c. O. puberula (Rich.) Nees; - c1. folha (face abaxial); c2. flor (§̊); c3. tépala; c4. estame série I; c5. estame série III; c6. pistilo; c7. fruto. d. O. pulchella (Nees \& Mart.) Mez - d1. ramo com flores; d2. folha (face abaxial); d3. flor ( đ); d4. tépala; d5. estame série I; d6. estame série III; d7. fruto. e. O. silvestris Vattimo-Gil - e1. folha (face abaxial); e2. tépala; e3. estame série I; e4. estame série III; e5. pistilo; e6. fruto. (a1-a7 Brotto 114; a8 Brotto 3; b1-b5 Soares e Silva 189; b6 Pastore 155; c1,c7 Brotto 383; c2-c5 Brotto 138; c6 Brotto 375; d1-d6 Brotto 312; d7 Brotto 387; e1,e6 Ziller 983; e2-e4 Silva 2262; e5 Dias 504).

Figure 5 - a. Ocotea porosa (Nees \& Mart.) Barroso - a1. leaf (abaxial surface); a2. flower; a3. tepal; a4. stamen series I; a5. stamen series III; a6. staminode series IV; a7. pistil; a8. fruit. b. O. prolifera (Nees \& Mart.) Mez - b1. leaf (abaxial surface); b2. tepal; b3. stamen series I; b4. stamen series III; b5. pistil; b6. fruit. c. O. puberula (Rich.) Nees - c1. leaf (abaxial surface); c2. flower ( $\lesssim$ ); c3. tepal; c4. stamen series I; c5. stamen series III; c6. pistil; c7. fruit. d. O. pulchella (Nees \& Mart.) Mez - d1. flowering branch; d2. leaf (abaxial surface); d3. flower (ठ); d4. tepal; d5. stamen series I; d6. stamen series III; d7. fruit. e. O. silvestris Vattimo-Gil - e1. leaf (abaxial surface); e2. tepal; e3. stamen series I; e4. stamen series III; e5. pistil; e6. fruit. (a1-a7 Brotto 114; a8 Brotto 3; b1-b5 Soares e Silva 189; b6 Pastore 155; c1,c7 Brotto 383; c2-c5 Brotto 138; c6 Brotto 375; d1-d6 Brotto 312; d7 Brotto 387; e1,e6 Ziller 983; e2-e4 Silva 2262; e5 Dias 504). 
limite austral de ocorrência sob $25^{\circ}$ de latitude, sendo categorizada nos critérios da IUCN (2001) como Em Perigo (EN Blab(iii)). Em material vivo a coloração das flores varia entre branca, creme e esverdeada, exalando um odor suave. Assis (2009) na revisão do grupo indica que o conceito até então tratado por Baitello (2003) como Ocotea indecora (Schott) Mez é na verdade $O$. prolifera. Na análise dos fototipos optou-se por aceitar o conceito de Assis (2009). Floresce de dezembro a março e frutifica de março a dezembro.

\section{Ocotea puberula (Rich.) Nees, Syst. Laur.: 472.} 1836.

Fig. 5c1-c7

Árvores, $20 \mathrm{~m}$ alt.; ramos angulosos, glabros. Folhas alternas; pecíolo 1-2,5 cm compr., canaliculado, glabro; lâmina $7-15 \times 2-5 \mathrm{~cm}$, ovada ou estreito-elíptica, ápice acuminado, base cuneada ou obtusa, margem ondulada, fortemente revoluta, face adaxial glabra, reticulação densa, nervuras planas, face abaxial glabrescente, reticulação densa, nervura primária saliente, secundárias subsalientes, 8-13 pares, ângulo de divergência $30^{\circ}-65^{\circ}$, nervação broquidódroma, domácias ausentes. Inflorescências axilares ou subterminais; tirsóide 3-11 cm compr., multiflora, alvo-pubérula. Flores unissexuadas; estaminadas com pedicelo ca. $3 \mathrm{~mm}$ compr.; hipanto inconspícuo, internamente glabro; tépalas ca. $2,8 \mathrm{~mm}$ compr., elípticas, face abaxial pubérula, face adaxial glabra; estames das séries I e II ca. 2 mm compr., filetes $1 / 2$ do comprimento da antera, glabros, anteras ovalado-quadrangulares, ápice obtuso, glabras, locelos introrsos; estames da série III ca. 2,3 mm compr., filetes tão longos quanto as anteras, glabros, anteras retangulares, ápice truncado, glabras, locelos superiores laterais e inferiores lateral-extrorsos; estaminódios da série IV ausentes; pistiloide estipiforme, glabro; pistiladas com tépalas ca. 2,2 mm compr., elípticas; estaminódios ca. 1 mm compr.; pistilo ca. $2 \mathrm{~mm}$ compr., glabro, ovário globoso, estilete um pouco mais curto, estigma capitado. Cúpulas $1 \times 0,6 \mathrm{~cm}$, infundibuliformes, margem simples. Frutos 1,4 × 1,1 cm, elipsoides.

Material examinado: Adrianópolis, 20.X.2009, fr., M.L. Brotto \& G. Vasconcellos 383 (FUEL, MBM, NY, RB, SPSF, UPCB). Antonina, 11.VIII.2009, fr., M.L. Brotto et al. 368 (MBM, NY, UPCB). Curitiba, 15.IX.2009, fl. (ㅇ), M.L. Brotto 375 (MBM, NY, SPSF, RB, UPCB). Londrina, 24.VII.1991, fl., F. Chagas e Silva 1400 (FUEL, HFC, MBM). Morretes, 14.V.2008, fl. (ठَ), M.L. Brotto et al. 138 (MBM, SPSF, UPCB).

No Paraná Ocotea puberula é encontrada na FOD Submontana, Montana, FOM e FES, entre 3 e
$1.100 \mathrm{~m}$, ocupando o dossel. A espécie é frequente e amplamente distribuída no estado, apresentando boa regeneração em florestas secundárias em estágio inicial de sucessão, sendo categorizada nos critérios da IUCN (2001) como Menor Preocupação (LC). Em material vivo a coloração das flores varia de creme a esverdeada e os frutos maduros são pretos com cúpulas vermelhas. A madeira apresenta odor suave. Entre as espécies com flores unissexuadas é a única com folhas glabrescentes de base fortemente revoluta. Floresce de março a dezembro, com pico de floração entre julho e setembro, frutifica de julho a fevereiro, com pico de frutificação entre setembro e dezembro.

25. Ocotea pulchella (Nees \& Mart.) Mez, Jahrb. Königl. Bot. Gart. Berlin 5: 317. 1889.

Fig. 5d1-d7

Arbustos ou árvores, $20 \mathrm{~m}$ alt.; ramos cilíndricos, aureo-pubérulos. Folhas alternas; pecíolo 0,3-1 cm compr., canaliculado, pubérulo; lâmina 4-10 × 1,5-3,5 cm, estreito-elíptica ou elíptica, ápice arredondado, obtuso ou acuminado, base cuneada, revoluta, face adaxial glabrescente, lustrosa, reticulação densa, nervuras planas, face abaxial glabrescente, reticulação densa, nervuras subsalientes, secundárias 4-6 pares, ângulo de divergência $25^{\circ}-50^{\circ}$, nervação broquidódroma, domácias nas axilas, cobertas por tricomas alvos. Inflorescências axilares; botrióide ou tirsóide 1-5 cm compr., em geral pauciflora, aureo-pubérula. Flores unissexuadas; estaminadas com pedicelo ca. $3 \mathrm{~mm}$ compr.; hipanto conspícuo, internamente glabrescente; tépalas 1,8-2,3 mm compr., ovaladoelípticas, reflexas, face abaxial pubérula, face adaxial glabra, papilas inconspícuas na margem; estames das séries I e II 1,1-1,8 mm compr., filetes tão longos quanto ou pouco menores que as anteras, glabros, anteras ovalado-retangulares, ápice obtuso, glabras, locelos introrsos; estames da série III ca. 1,5 mm compr., filetes tão longos quanto as anteras, glabros, anteras retangulares, contraídas no meio, ápice truncado, glabras, locelos superiores laterais e inferiores lateral-extrorsos; estaminódios da série IV inconspícuos ou ausentes; pistiloide filiforme, glabro; pistiladas com estaminódios 0,5-1,1 mm compr.; pistilo 1,5-2,3 mm compr., glabro, ovário globoso, estilete um pouco mais curto, estigma capitado. Cúpulas ca. $0,9 \times 0,9 \mathrm{~cm}$, sub-hemisféricas a hemisféricas, margem simples. Frutos ca. 1,1 $\times$ $0,8 \mathrm{~cm}$, ovalados ou elipsoides, ápice mucronado. Material selecionado: Arapoti, 27.XI.1959, fl., G.G. Hatschbach 6549 (MBM, RB, UPCB). Bituruna, 13.II.1966, fl., G.G. Hatschbach et al. 13872 (MBM, RB, 
UPCB). Morretes, 2.XII.2009, fr., M.L. Brotto et al. 398 (MBM, NY, RB, SPSF, UPCB).Paranaguá, 2.XI.2009, fr., M.L. Brotto 387 (MBM, UPCB). Pontal do Paraná, 12.III.2009, fl. (ð), M. L. Brotto 312 (FUEL, MBM, NY, $\mathrm{RB}, \mathrm{UPCB})$.

No Paraná Ocotea pulchella é encontrada na FOD das Terras Baixas, Submontana, Montana, Altomontana, Formação Pioneira com Influência Marinha e Fluviolacustre, FOM e Savana, entre 3 e $1.320 \mathrm{~m}$, ocupando o dossel. A espécie é frequente e amplamente distribuída no estado, com exceção do terceiro planalto, sendo categorizada nos critérios da IUCN (2001) como Menor Preocupação (LC). É especialmente abundante em vegetação pioneira onde adquire porte arbustivo, mas também pode ser comum em florestas bem desenvolvidas do planalto e Serra do Mar. Em material vivo a coloração das flores varia entre branca, alva e creme e os frutos maduros são pretos com cúpulas avermelhadas. A madeira apresenta odor moderado. Vegetativamente difere de O. tristis (Nees \& Mart.) Mez pelas folhas com reticulação densa na face adaxial e de $O$. bicolor e $O$. paranensis pela presença de domácias. Floresce de fevereiro a maio e setembro, com pico de floração entre fevereiro e abril, frutifica de maio a janeiro e março, com pico de frutificação entre agosto e novembro.

26. Ocotea silvestris Vattimo-Gil, Arch. Jard. Bot. Rio de Janeiro 16: 43. $1958 . \quad$ Fig. 5e1-e6

Árvores, $25 \mathrm{~m}$ alt.; ramos subcilíndricos, aureo-glabrescentes. Folhas alternas; pecíolo 0,5-1 cm compr., ca. 0,1 cm espessura, subcanaliculado, glabrescente; lâmina 5-14 × 1,5-4,5 cm, cartáceocoriácea, elíptica ou ovado-elíptica, ápice agudo ou acuminado, base cuneada, face adaxial glabra, reticulação densa, nervura primária subsaliente, nervuras secundárias planas, face abaxial glabrescente, reticulação densa, nervura primária saliente, secundárias subsalientes, 5-8 pares, ângulo de divergência $30^{\circ}-60^{\circ}$, nervação broquidódroma, domácias ausentes. Inflorescências axilares ou subterminais; tirsóide 2-5 cm compr., pauciflora, aureo-pubérula. Flores unissexuadas, pubérulas; estaminadas com pedicelo 2-3 mm compr.; hipanto inconspícuo, internamente pubérulo; tépalas ca 2,9 mm compr., ovalado-elípticas, pubérulas em ambas as faces, papilas inconspicuas na magem e no ápice; estames das séries I e II ca. 2 mm compr., filetes tão longos quanto as anteras, pubérulos, anteras ovalado-triangulares, ápice obtuso, glabras, locelos introrsos; estames da série III ca. 1,8 mm compr., filletes tão longos quanto as anteras, pubérulos, anteras retangulares, ápice truncado, glabras, locelos superiores laterais e inferiores lateral-extrorsos; estaminódios da série IV ausentes; pistiloide estipiforme, pubérulo; pistiladas com estaminódios 1-1,3 mm compr.; pistilo ca. $2 \mathrm{~mm}$ compr., glabro, ovário elipsoide, estilete um pouco mais curto, estigma capitado. Cúpulas ca. 1,2 × 1,2 $\mathrm{cm}$, obcônicas, margem dupla. Frutos ca. $2 \times 1,2$ $\mathrm{cm}$, elipsoides.

Material selecionado: Capitão Leônidas Marques, 23.VIII.2004, fr., E. Barbosa \& E.F. Costa 984 (MBM, RB). Guaraqueçaba, 18.X.1995, fr., S.R. Ziller \& W. Maschio 983 (HFC, MBM). Ibiporã, 18.XII.1991, fl., F. Chagas e Silva 1476 (FUEL, MBM, UPCB). Tijucas do Sul, 7.II.1998, fl. (ð), J.M. Silva et al. 2262 (MBM). Xambrê, 27.I.1962, fl., R. Reitz \& R. Klein 12093 (HBR, $\mathrm{RB}, \mathrm{SP})$.

Material adicional: BRASIL. SÃO PAULO: São Miguel Arcanjo, 25.III.1994, fl. (q), A.C. Dias \& R.O. Pinto 504 (MBM).

No Paraná Ocotea silvestris é encontrada na FOD Submontana e Montana, FOM e FES, entre 250 e $1.100 \mathrm{~m}$, ocupando o dossel. A espécie amplamente distribuída no estado, sendo frequente na FES e FOM e rara na FOD, por isso é categorizada nos critérios da IUCN (2001) como Menor Preocupação (LC). Em material vivo a coloração das flores varia de branca a creme. Pode ser confundida com $O$. glaziovii, mas nessa os pecíolos são mais espessos e os frutos são globosos de margem simples ou hexalobada. Floresce de dezembro a maio e frutifica de abril a dezembro.

27. Ocotea teleiandra (Meisn.) Mez, Jahrb. Königl. Bot. Gart. Berlin 5: 382. $1889 . \quad$ Fig. 6a1-a7

Árvores, $8 \mathrm{~m}$ alt.; ramos subcilíndricos, glabros. Folhas alternas ou subopostas no ápice dos ramos; pecíolo 0,5-1 cm compr., canaliculado, glabro; lâmina $3-12 \times 1-5,5 \mathrm{~cm}$, elíptica ou obovada, ápice caudado, base atenuada, margem ondulada, face adaxial glabra, reticulação obscura, nervuras planas, face abaxial glabra, reticulação laxa, nervuras planas, secundárias 4-5 pares, ângulo de divergência $25^{\circ}-60^{\circ}$, nervação camptódromabroquidódroma, domácias ausentes. Inflorescências axilares ou subterminais; tirsóide 3-6 cm compr., pauciflora, glabra. Flores unissexuadas; estaminadas com pedicelo 2-3 mm compr.; hipanto inconspícuo, internamente pubérulo; tépalas 1,3-2,2 mm compr., elípticas ou estreito-elípticas, face abaxial glabra, face adaxial papilosa, papilas na margem; estames das séries I e II 0,8-1 mm compr., filetes $1 / 4$ a $1 / 5$ do comprimento das anteras, pubescentes, anteras quadrangulares, ápice obtuso, inconspicuamente 
papilosas, locelos introrsos; estames da série III ca. 1 mm compr., filetes pouco mais curtos que as anteras, pubescentes, anteras ovalado-retangulares, ápice truncado, locelos superiores laterais a subintrorsos e inferiores lateral-extrorsos; estaminódios da série IV e pistiloide ausentes; pistiladas com estaminódios 0,5-0,7 mm compr., pistilo ca. 1,3 mm compr., glabro, ovário elipsoide, estilete muito curto, estigma lobado. Cúpulas 1,3 × $2 \mathrm{~cm}$, sub-hemisféricas, margem simples. Frutos $3 \times 1,6 \mathrm{~cm}$, elipsoides.

Material selecionado: Adrianópolis, 25.XI.2008, fl. (ð), M.L. Brotto \& G. Vasconcellos 254 (FUEL, MBM, NY, RB, UPCB). Guaratuba, 6.XI.1960, fl. (ð), G.G. Hatschbach 7412 (MBM, RB, UPCB). Morretes, 29.III.2009, fr., M.L. Brotto 326 (MBM, RB, UPCB); 2.XII.2009, fl. (む), M.L. Brotto et al. 404 (MBM, RB, UPCB). Paranaguá, s.d., fl. (q) e fr., E. Moreira 361 (UPCB).

No Paraná Ocotea teleiandra é encontrada na FOD das Terras Baixas, Submontana, Montana, Aluvial e Formação Pioneira de Influência Fluviolacustre, entre 3 e 1.080 m, ocupando o sub-bosque. A espécie é frequente e amplamente distribuída no Leste do estado sendo categorizada nos critérios da IUCN (2001) como Menor Preocupação (LC). Das espécies de sub-bosque é a mais comum, preferindo florestas primárias ou secundárias em estágio médio e avançado de sucessão. Em material vivo a coloração das flores varia de branca a creme e os frutos maduros são pretos com cúpulas vermelhas. Floresce de julho a fevereiro, com pico de floração entre novembro e dezembro, frutifica durante o ano todo.

28. Ocotea tristis (Nees \& Mart.) Mez, Jahrb. Königl. Bot. Gart. Berlin 5: 316. 1889.

Fig. 6b1-b7

Arbustos ou pequenas árvores, 4,5 m alt.; ramos cilíndricos, glabrescentes. Folhas alternas; pecíolo 0,4-1 cm compr., canaliculado, glabrescente; lâmina 2,5-6 × 1,5-3 cm, obovado-elíptica, ápice obtuso a acuminado, base obtusa a cuneada, face adaxial glabra, lustrosa, bulada sobre as domácias, reticulação laxa, nervuras subsalientes, face abaxial glabrescente, reticulação laxa, nervura primária saliente, secundárias subsalientes, 4-6 pares, ângulo de divergência $25^{\circ}-60^{\circ}$, nervação camptódroma-broquidódroma, domácias nas axilas, cobertas por tricomas alvos. Inflorescências axilares ou subterminais; botrióide 1-3 cm compr., pauciflora, aureo-pubérula. Flores unissexuadas; estaminadas com pedicelo ca. 3 mm compr.; hipanto inconspícuo, internamente glabrescente; tépalas 1,7-2,2 mm compr., ovaladoelípticas, face abaxial pubérula, face adaxial glabra, papilas inconspícuas na margem e no ápice; estames das séries I e II 1-1,7 mm compr., filetes tão longos quanto ou pouco menores que as anteras, glabros, anteras ovalado-retangulares, ápice obtuso, glabras, locelos introrsos; estames da série III 1,1-1,8 $\mathrm{mm}$ compr., filetes tão longos quanto as anteras, glabros, anteras retangulares, contraídas no meio, ápice truncado, glabras, locelos superiores laterais e inferiores lateral-extrorsos; estaminódios da série IV inconspícuos ou ausentes; pistiloide filiforme, glabro; pistiladas com estaminódios 0,5-1 mm compr.; pistilo 1,7-2 mm compr., glabro, ovário globoso, estilete um pouco mais curto, estigma capitado. Cúpulas $0,5 \times 0,5$ $\mathrm{cm}$, sub-hemisféricas, margem simples. Frutos 1,2 $\times$ $0,9 \mathrm{~cm}$, elipsoides ou globosos.

Material selecionado: Arapoti, 10.III.1960, fl., G.G. Hatschbach 6900 (HBR, MBM, RB). Balsa Nova, 29.XI.2009, fr., M.L. Brotto 396 (UPCB). Guaratuba, 30.III.2007, fl. ()), M.L. Brotto \& E.P. Santos 18 (RB, UPCB). Jaguariaíva, 21.V.2009, fl. (ठ઼), M.L. Brotto 357 (MBM, UPCB). Morretes, 29.III.2009, fl. (ð), M.L. Brotto 323 (FUEL, MBM, NY, RB, UPCB).

No Paraná Ocotea tristis é encontrada na FOD Altomontana e Refúgio Vegetacional, Savana e Estepe, entre 1.030 e 1.820 m. A espécie é frequente e amplamente distribuída em regiões altas da Serra do Mar e do segundo planalto do Paraná sendo categorizada nos critérios da IUCN (2001) como Menor Preocupação (LC). Em material vivo a coloração das flores varia entre branca, alva, creme e esverdeada e os frutos maduros são pretos com cúpulas vermelhas. Coletas provenientes do segundo planalto apresentam folhas com ápice obtuso a arredondado e frutos nitidamente elipsóides, enquanto que as provenientes da Serra do Mar apresentam folhas com ápice agudo a acuminado e frutos globosos. Floresce de janeiro a agosto, com pico de floração entre fevereiro e abril, frutifica de maio a janeiro, com pico de frutificação entre setembro e novembro.

29. Ocotea vaccinioides (Meisn.) Mez, Jahrb. Königl. Bot. Gart. Berlin 5: 252. 1889.

Fig. 6c1-c7

Árvores, gimnodióica, $12 \mathrm{~m}$ alt.; ramos cilíndricos, glabrescentes. Folhas alternas; pecíolo 0,5-0,8 cm compr., glabrescente; lâmina 3,5-7 × 1-2 $\mathrm{cm}$, lanceolada ou estreito-elíptica, ápice agudo, base cuneada, face adaxial glabrescente, reticulação laxa, conspícua, nervura primária subsaliente, secundárias planas, face abaxial não enrugada ou plissada, aureopubescente, reticulação laxa, conspícua, nervura primária saliente, secundárias subsalientes, 5-8 pares, ângulo de divergência $30^{\circ}-60^{\circ}$, nervação 


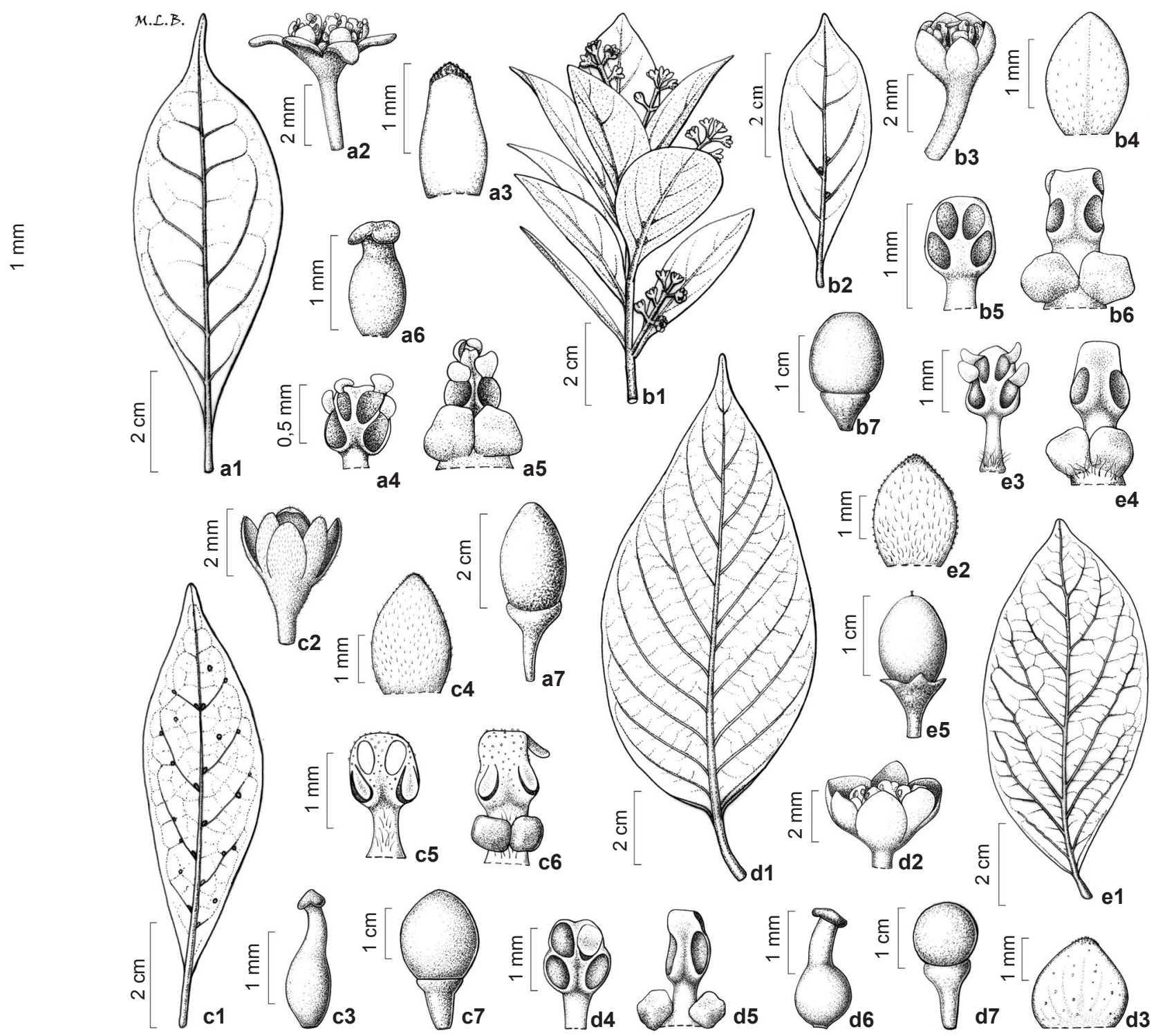

Figura 6 - a. Ocotea teleiandra (Meisn.) Mez - a1. folha (face abaxial); a2. flor (つ̋); a3. tépala; a4. estame série I; a5. estame série III; a6. pistilo; a7. fruto. B. O. tristis (Nees \& Mart.) Mez - b1. ramo com flores; b2. folha (face abaxial); b3. flor (ふ̋); b4. tépala; b5. estame série I; b6. estame série III; b7. fruto. c. O. vaccinioides (Meisn.) Mez - c1. folha (face abaxial); c2. flor (§̊); c3. pistilo; c4. tépala; c5. estame série I; c6. estame série III; c7. fruto. d. $O$. velloziana (Meisn.) Mez - d1. folha (face abaxial); d2. flor (đ̊); d3. tépala; d4. estame série I; d5. estame série III; d6. pistilo; d7. fruto. e. O. veluitna (Nees) Rohwer - e1. folha (face abaxial); e2. tépala; e3. estame série I; e4. estame série III; e5. fruto. (a1-a5 Brotto 404; a6 Moreira 361; a7 Brotto 326; b1-b6 Brotto 323; b7 Brotto 396; c1,c7 Brotto 392; c2-c3 Dala Rosa 83; c4-c6 Völtz 11; d1-d5 Hatschbach 7866; d6 Hatschbach 9072; d7 Silva 2524; e1-e4 Cesar SPSF 35140; e5 Marestoni 18).

Figure 6 - a. Ocotea teleiandra (Meisn.) Mez - a1. leaf (abaxial surface); a2. flower ( $\overbrace{}^{\Uparrow})$; a3. tepal; a4. stamen series I; a5. stamen series III; a6. pistil; a7. fruit. b. O. tristis (Nees \& Mart.) Mez - b1. flowering branch; b2. leaf (abaxial surface); b3. flower ( $\left.{ }^{\Uparrow}\right)$; b4. tepal; b5. stamen series I; b6. stamen series III; b7. fruit. c. O. vaccinioides (Meisn.) Mez - c1. leaf (abaxial surface); c2. flower (ठ̊); c3. pistil; c4. tepal; c5. stamen series I; c6. stamen series III; c7. fruit. d. O. velloziana (Meisn.) Mez - d1. leaf (abaxial surface); d2. flower (ふ); d3. tepal; d4. stamen series I; d5. stamen series III; d6. pistil; d7. fruit. E. O. veluitina (Nees) Rohwer; e1. leaf (abaxial surface); e2. tepal; e3. stamen series I; e4. stamen series III; e5. fruit. (a1-a5 Brotto 404; a6 Moreira 361; a7 Brotto 326; b1-b6 Brotto 323; b7 Brotto 396; c1,c7 Brotto 392; c2-c3 Dala Rosa 83; c4-c6 Völtz 11; d1-d5 Hatschbach 7866; d6 Hatschbach 9072; d7 Silva 2524; e1-e4 Cesar SPSF 35140; e5 Marestoni 18). 
broquidódroma, domácias nas axilas e extra-axilares, com abertura comprimida ou orbicular, cobertas ou não por tricomas. Inflorescências axilares; tirsóide 2-7 cm compr., pauciflora ou multiflora, aureotomentosa. Flores bissexuadas; pedicelo ca. 1,5 $\mathrm{mm}$ compr.; hipanto inconspícuo, internamente tomentoso; tépalas $2,4-2,5 \mathrm{~mm}$ compr., elípticas, face abaxial tomentosa, face adaxial papilosa e tomentosa; estames das séries I e II 1,2-1,8 mm compr., filetes igual ou mais curtos que as anteras, glabrescentes, anteras ovalado-quadrangulares, ápice obtuso, glabras, locelos introrsos; estames da série III 1,5-2 mm compr., filetes tão longos quanto as anteras, glabrescentes, anteras ovalado-retangulares, ápice truncado, glabras, locelos superiores laterais e inferiores lateral-extrorsos; estaminódios da série IV ca. $0,6 \mathrm{~mm}$ compr., filiformes, pubérulos; pistilo 1,8-2,2 mm compr., glabro, ovário globoso, estilete longo, estigma subcapitado; Flores unissexuadas; pistiladas com estaminódios ca. 0,8 mm compr.; pistilo ca. 1,8 mm compr., glabro, ovário elipsoide, estilete curto, estigma subcapitado. Cúpulas 1,2 $\times$ $0,9 \mathrm{~cm}$, tropetiformes, margem simples. Frutos $2 \times$ $1,3 \mathrm{~cm}$, elipsoides.

Material selecionado: Guaratuba, 31.IX.2006, fr., M.L. Brotto et al. 5 (MBM, UPCB). Morretes, 8.II.2000, fl. (ㅇ), S. Dala Rosa 83 (UPCB); 7.XI.2009, fr., M.L. Brotto \& C.T. Blum 392 (MBM, RB, SPSF, UPCB).Quatro Barras, 31.I.1989, fl. (ㅇ), J.M. Silva \& J. Cordeiro 615 (MBM); 1.II.2009, fl. (đ), R.R. Völtz \& M.L. Brotto 11 (UPCB).

No Paraná Ocotea vaccinioides é encontrada na FOD Montana e Altomontana, entre 820 e 1.530 $\mathrm{m}$, ocupando o dossel. A espécie é frequente e amplamente distribuída no Leste do estado, mas apenas na metade superior das montanhas da Serra do Mar, por isso categorizada nos critérios da IUCN (2001) como Quase Ameaçada (NT). Em material vivo a coloração das flores varia de alva a creme e os frutos maduros apresentam cúpulas vermelhas. A madeira apresenta odor acentuado. Floresce de dezembro a março e frutifica de abril a novembro.

30. Ocotea velloziana (Meisn.) Mez, Jahrb. Königl. Bot. Gart. Berlin 5: 347. 1889. Fig. 6d1-d7

Árvores, $10 \mathrm{~m}$ alt.; ramos angulosos, aureotomentosos. Folhas alternas a subopostas; pecíolo 1-2 cm compr., subcanaliculado, aureo-tomentoso; lâmina 7-14 × 3-7 cm, ovada, ápice agudo, base obtusa, revoluta, face adaxial glabrescente, tomentosa sobre as nervuras, reticulação subdensa, nervura primária subsaliente, secundárias planas, face abaxial tomentosa, reticulação subdensa, nervuras salientes, 9-11 pares, ângulo de divergência $30^{\circ}-60^{\circ}$, nervação broquidódroma, domácias ausentes. Inflorescências axilares ou subterminais; tirsóide 2-14 cm compr., multiflora, aureo-tomentosa. Flores unissexuadas; estaminadas com pedicelo ca. $1 \mathrm{~mm}$ compr.; hipanto inconspícuo, internamente glabrescente; tépalas ca. 2,2 mm compr., ovalado-elípticas, glabras em ambas as faces, papilas inconspícuas na margem; estames das séries I e II ca. 1,7 mm compr., filetes 1/2 do comprimento das anteras, glabrescentes, anteras ovaladas, contraídas no meio, ápice contraído, glabras, locelos introrsos; estames da série III 1,7-1,9 mm compr., filetes $1 / 2$ do comprimento das anteras, glabros, anteras retangulares, ápice truncado, glabras, locelos superiores laterais e inferiores lateral-extrorsos; estaminódios da série IV ausentes; pistilóide filiforme, glabro; pistiladas com estaminódios ca. $1 \mathrm{~mm}$ compr., pistilo 2-2,4 mm compr., glabro, ovário globoso, tão longo quanto o ovário, estigma lobado. Cúpulas ca. $0,9 \times 0,7 \mathrm{~cm}$, obcônicas, glabras, margem simples. Frutos ca. $0,9 \times 0,9 \mathrm{~cm}$, globosos.

Material selecionado: Diamante do Norte, 6.IX.1998, fr., J.M. Silva et al. 2524 (FUEL, MBM). Guaíra, 9.IV.1961, f1. (ठ)), G.G. Hatschbach 7866 (MBM).Jaguariaíva, 14.IV.1962, fl. ()), G.G. Hatschbach 9072 (MBM, SP). Sengés, 4.V.2006, fl., E. Barbosa \& F. Costa 1332 (MBM). Ventania, 31.X.2010, fr., D.A. Estevan et al. 206 (FUEL, SPSF).

No Paraná Ocotea velloziana é encontrada na Savana, entre 265 e $1.000 \mathrm{~m}$, ocupando o dossel. A espécie é rara no estado, embora sua ocorrência em remanescentes de Savana sugira uma ampla distribuição no Norte do Paraná, por isso á categorizada nos critérios da IUCN (2001) como Em Perigo (EN B1ab(iii)). Em material vivo a coloração das flores é creme e os frutos maduros apresentam cúpulas avermelhadas. Assemelha-se a Ocotea velutina (Nees) Rohwer que apresenta pecíolos com $0,5-1 \mathrm{~cm}$ de comprimento, flores tomentosas reunidas em glomérulos e cúpulas tomentosas de margem hexalobada, enquanto que $O$. velloziana apresenta pecíolos com 1-2 cm de comprimento, flores glabrescentes não reunidas em glomérulos e cúpulas glabras de margem simples. Floresce de março a julho e frutifica de julho a novembro.

31. Ocotea velutina (Nees) Rohwer, Mitt. Inst. Allg. Bot. Hamburg 20: 172. $1986 . \quad$ Fig. 6e1-e5 Árvores, $10 \mathrm{~m}$ alt.; ramos angulosos, aureotomentosos. Folhas alternas a subopostas; pecíolo 0,5-1 cm compr., subcanaliculado, aureo-tomentoso; lâmina 8-22 × 4,5-9 cm, elíptica ou obovada, ápice agudo, base cuneada, face adaxial glabrescente, tomentosa sobre as nervuras, reticulação subdensa, nervura primária imersa, secundárias planas, face 
abaxial tomentosa, reticulação subdensa, nervuras salientes, $7-9$ pares, ângulo de divergência $25^{\circ}-45^{\circ}$, nervação broquidódroma, domácias ausentes. Inflorescências axilares ou subterminais; tirsóide 3-15 cm compr., multiflora, aureo-tomentosa. Flores unissexuadas; estaminadas com pedicelo ca. $1 \mathrm{~mm}$ compr.; hipanto inconspícuo, internamente tomentoso; tépalas ca. 2,5 mm compr., ovaladoelípticas, tomentosas em ambas as faces, papilas na margem e no ápice; estames das séries I e II ca. 2,1 mm compr., filetes tão longos quanto as anteras, tomentosos, anteras ovaladas, ápice obtuso, glabras, locelos introrsos; estames da série III ca. 2,1 mm compr., filetes tão longos quanto as anteras, tomentosos, anteras retangulares, ápice truncado, glabras, locelos superiores lateral-introrsos e inferiores lateral-extrorsos; estaminódios da série IV ausentes; pistilóide filiforme, glabro; pistiladas não vistas. Cúpulas ca. $0,8 \times 0,8 \mathrm{~cm}$, obcônicas, tomentosas, margem hexalobada. Frutos ca. 1,2 $\times$ $0,9 \mathrm{~cm}$, elipsoides.

Material selecionado: Lupionópolis, 26.VII.2007, fr., T.M. Marestoni et al. 18 (FUEL, SPSF).

Material adicional: BRASIL. SÃO PAULO: Anhembi, 14.V.1982, fl. (ð)), Cesar (SPSF 35140).

Ocotea velutina é citada pela primeira vez no Paraná, onde é encontrada na Savana, a cerca de $400 \mathrm{~m}$, ocupando o dossel. A espécie é rara no estado, conhecida por apenas uma coleta, entretanto, essa raridade pode estar relacionada com seu limite austral de ocorrência, a região limítrofe entre o Norte do Paraná e Oeste de São Paulo, por isso é categorizada nos critérios da IUCN (2001) como Em Perigo Crítico (CR). Entre as Ocotea no Paraná, é a única com flores reunidas em glomérulos e cúpulas pilosas. Floresce em maio e frutifica de julho a agosto.

\section{Agradecimentos}

Os autores agradecem ao CNPq pela concessão de bolsas, de mestrado para o primeiro autor e Produtividade em Pesquisa para o segundo e terceiro autores.

\section{Referências}

Assis, L.C.S. 2009. Sistemática e filosofia: filogenia do complexo Ocotea e revisão do grupo Ocotea indecora (Lauraceae). Tese de Doutorado. Instituto de Boiciências da Universidade de São Paulo, São Paulo. 238p.

Assis, L.C.S. \& Mello-Silva R. 2010. Taxonomic and nomenclatural changes in the Ocotea indecora group (Lauraceae). Novon 20: 377-380.
Aublet, J.B.C.F. 1775. Histoire des plantes de la Guiane Françeise. Vol. 2. Pp. 780-784.

Baitello, J.B. (coord.) 2003. Lauraceae. In: Wanderley, M.G.L.; Shepherd, G.; Giulietti, A.M. \& Melhem, T.M. (eds.). Flora fanerogâmica do estado de São Paulo. Vol. 3. FAPESP/RiMa, São Paulo. Pp. 149-223.

Brotto, M.L.; Santos, E.P. \& Baitello, J.B. 2009. Lauraceae no Morro dos Perdidos (Floresta Atlântica), Paraná, Brasil. Rodriguésia 60: 445-459.

Brotto, M.L.; Baitello, J.B.; Cervi, A.C. \& Santos, E.P. 2010. Uma nova espécie de Ocotea (Lauraceae) para o Brasil. Rodriguésia 61: S57-S60.

Brotto, M.L. \& Baitello, J.B. 2012. Uma espécie nova de Lauraceae da floresta atlântica do Brasil. Rodriguésia 63: 579-585.

Gentry, A. 1988. Changes in plant community diversity and floristic composition on environmental and geographical gradients. Annals of the Missouri Botanical Garden 69: 557-593.

Holmgren, P.K. \& Holmgren, N.H. 1998. Index Herbariorum: a global directory of public herbaria and associated staff. New York Botancial Garden's Virtual Herbarium. (continuously updated) Disponível em <http://sweetgum.nybg.org/ih>. Acesso em 15 Ago 2009.

IUCN - The International Union for Conservation of Nature. 2001. IUCN red list categories, v. 3.1. IUCN Species Survival Commission, Gland, Cambridge. Disponível em <http://www.iucnredlist.org/apps/ redlist/static/categories_criteria_3_1 $>$. Acesso em 9 Out 2009.

Lawrence, G.H.M. 1951. Taxonomy of vascular plants. The Macmillan Co., New York.

Meissner, C.F. 1864. Lauraceae. In: de Candolle, A.L.P.P. (ed.). Prodromus Systematis Naturalis Regni Vegetabilis. Victoris Masson et Filii, Parisiis. Vol. 15, pp 1-260.

Meissner, C.F. 1866. Lauraceae et Hernandiaceae. In: C.F.P. Martius \& A.G. Eichler (eds.). Flora brasiliensis. Lipsiae, Frid. Fleischer, 5: 137-308.

Mez, C. 1889. Lauraceae Americanae. Jahrbuch Königlichen botanischen Gartens Berlin, 5: 1-556.

Ministério do Meio Ambiente - MMA. 2008. Instrução Normativa n. 6 de 23/09/2008. Reconhece as espécies da flora brasileira ameaçadas de extinção.

Nees Von Esenbeck, C.G.D. 1833. Revisio Laurinarum ab Sellowio in Brasilia collectarum et iam in Herbario Regio Berolinensi asservatarum. Linnaea 8: 36-51.

Nees Von Esenbeck, C.G.D. 1836. Systema Laurinarum. Sumtibus Veitii et Sociorum, Berolini. 720p.

Quinet, A. \& Andreata, R.H.P. 2002. Lauraceae Jussieu na Reserva Ecológica de Macaé de Cima, Município de Nova Friburgo, Rio de Janeiro, Brasil. Rodriguésia 53: 59-121.

Quinet, A.; Baitello, J.B.; Moraes, P.L.R.; Alves, F.M. \& Assis, L. 2012. Lauraceae. In: Forzza, R.C. et al. (eds.). Lista de espécies da flora do Brasil. 
Jardim Botânico do Rio de Janeiro, Rio de Janeiro. Disponível em <http://floradobrasil.jbrj.gov. br/2012/FB000143>. Acesso em 15 Ago 2012.

Roderjan, C.V.; Galvão, F.; Kuniyoshi, Y.S. \& Santos, E.P. 2001. Caractérisation des unités phytogéographiques dans l'Etat du Paraná, Brésil, et leur état de conservation. Biogeographica, 77: 129-140.

Rohwer, J.G. 1986. Prodromus einer Monographie der Gattung Ocotea Aubl. (Lauraceae), sensu lato. Mitteilungen aus dem Institut fur Allgemeine botanik Hamburg. 278p.

Rohwer, J.G. 1993. Lauraceae. In: Kubitzki, K.; Rohwer, J.G. \& Bittrich, V. (eds.). The families and genera of vascular plants. Vol. 2. Springer-Verlag, Berlim. Pp. 366-391.

Scheer, M.B \& Blum, C.T. 2011. Arboreal diversity of the Atlantic Forest of Southern Brazil: from the beach ridges to the Paraná river. In: Grillo, O. \& Venora, G. (eds.). The dynamical processes of biodiversity - Case studies of evolution and spatial distribution. InTech. Pp. 109-134.

Van der Werff, H. 1991. A key to the genera of Lauraceae in the new world. Annals of the Missouri Botanical Garden 78: 377-387.
Van der Werff, H. \& Ritcher, H.G. 1996. Toward and improved classification of Lauraceae. Annals of the Missouri Botanical Garden 83: 409-418.

Vattimo-Gil, I. de. 1956a. Nota prévia sobre as espécies de Ocotea Aubl. que ocorrem no estado do Paraná. Arquivos do Serviço Florestal 10: 109-123.

Vattimo-Gil, I. de. 1956b. O gênero Ocotea Aubl. no Sul do Brasil. I. Espécies de Santa Catarina e Paraná. Rodriguésia 18-19: 265-350.

Vattimo-Gil, I. de. 1962. O gênero Ocotea Aubl. nos estados de São Paulo e Rio Grande do Sul. Apêndice: notas sobre o gênero Cinnamomum Boehm, no Brasil. Arquivos do Jardim Botânico do Rio de Janeiro 17: 199-226.

Vattimo-Gil, I. 1979. Contribuição ao conhecimento da distribuição geográfica das Lauráceas V. Novas localidades nos estados do Paraná e Rio Grande do Sul. Rodriguésia 31: 135-152.

Zanon, M.M.F.; Goldenberg, R. \& Moraes, P.L.R. de. 2009. O gênero Nectandra Rol. ex Rottb. (Lauraceae) no estado do Paraná, Brasil. Acta Botanica Brasilica 23: 22-35.

Weberling, F. 1989. Morphology of flowers and inflorescences. Cambridge University Press. 405p.

\section{Lista de coletores:}

Abrão, H.R.S. 193(24); Arbocz, G.F. 1031(5); Azevedo, T.I.N. de 260(19); Baitello, J.B. 209(3); Barbosa, E. 205(15), 984(26), 1332(30); Barreto, K.D. 2431(31); Barros, F. de 2121(5); Beltrami, L. 3(24); Bianchini, E. s.n. FUEL 12540(13); Bianek, A.E. 16(25); Blum, C.T. 205(26); Bolson, M. 183(19); Brina, A.E. s.n. MBM 214360(31); Britez, R.M. 291(24), 1240(20), 1376(7), 2141(25); Brotto, M.L. 3(22), 5(29), 11(10), 18(28), 26(15), 40(20), 46(2), 50(25), 77(19), 79(22), 113(28), 114(22), 129(4), 138(24), 152(2), 208(6), 241(22), 246(2), 249(24), 254(27), 255(4), 267(6), 279(2), 284(20), 285(2), 301(22), 312(25), 313(25), 315(22), 323(28), 326(27), 347(4), 349(25), 357(28), 363(18), 368(24), 374(12), 375(24), 378(18), 381(20), 382(20), 383(24), 386(1), 387(25), 389(2), 392(29), 395(2), 396(28), 398(25), 399(9), 400(22), 403(16), 404(27), 406(27), 410(2), 411(16), 414(20), 440(12), 447(15), 500(25), 502(24), 503(10), 592(4), 621(20), 623(9), 625(25), 628(20), 632(2), 643(2), 658(19), 662(4), 712(23), 797(12); Bufrem, A. 3(19); Buturra 209(24); Camargo, E.H. 42(19); Canha, A.M. s.n. UPCB 41743(14); Carneiro, J. 816(26), 1143(24); Carpanezzi, A.A. s.n. HFC 8092(24); Carvalho, P.E. 12(7), 23(22), 171(24), 183(19); Cavalheiro, A.L. s.n. FUEL 24670(19), FUEL 24719(26), UPCB 44125(26); Caxambu, M.G. 73(24), 269(5), 758(26), 802(24), 908(14), 1673(10), 1706(22), 2434(22), 2631(26), 3064(7); Celso, A. s.n. SPSF 10817(31); Cerqueira, R.M. 22(11); Cervi, A.C. 2508(25), 3034(7), 3092(9); Cervigne, N.S. 94(10); Cesar s.n. SPSF 35140(31); Chagas e Silva, F. 1400(24), 1476(26); 1580(10), 1583(5), 1884(5); Coelho, V.C.B. 10(19); Cordeiro, J. 569(19); Cruz, J. da 82(24), 104(25); Dala Rosa, S. 83(29); Dalmas, B.B. s.n. HCF 6936(7); Dias, A.C. 504(26); Dias, M.C. s.n. FUEL 17577(23), RB 361755(23), UPCB 44120(23), FUEL 7531(24), FUEL 12448(26), HFC 5660(26); Duarte, A.P. 5384(24), 5875(17); Dunaiski Jr., A. 574(25), 2230(21); Estevan, D.A. 48(2), 99(12), 115(22), 206(30), 298(7), 479(22), 787(2), 1080(7), 1081(10); Eupunino, A. 336(17); Fadelli, L. 296(26), 304(7), s.n. FUEL 24359(24); Ferreira, J.A. s.n. FUEL 25712(24), FUEL 24715(25), HFC 5923(25); Ferreira, R.C. 28(12); Filipak, S.A. s.n. UPCB 33069(25); Fogaça, J.A. s.n. HCF 3140(24), MBM 323045(24); Forzza, R.C. 4241(13); Francisco, E.M. 91(22), s.n. FUEL 23308(10), FUEL 37582(7), FUEL 26847(19), FUEL 22174(24), FUEL 37588(24), FUEL 24256(24), HFC 5659(24), FUEL 37544(25), FUEL 23291(26); Furtado, P.P. 132(26), 165(7); Gatti, A.L.S. 156(24); Gatti, G. 150(2), 331(19); Gaudens, E.G. s.n. FUEL 1121(13); Gomes e Mattos 1217(10); Goetzke, S. 160(24); Guapyassú, M. 309(24); Hatschbach, G.G. 1152(25), 1285(25), 3083(24), 3641(25), 3956(25), 3959(28), 4866(24), 5148(22), 5275(5), 5507(28), 5511(25), 6549(25), 6650(20), 6900(28), 6998(20), 7139(26), 7207(12), 7253(19), 7412(27), 7426(4), 7438(22), 7455(25), 7456(2), 7506(6), 7571(27), 7597(17), 7672(22), 7866(30), 8875(20), 9072(30), 9082(12), 9199(8), 9522(2), 9666(2), 9879(17), 10101(10), 10686(25), 10918(25), 11924(2), $12120(28), 12743(14), 12746(1), 12760(8), 12917(7), 13040(22), 13078(9), 13256(5), 13473(28), 13574(26), 13668(22), 13736(22)$, $13819(22), 13872(25), 14248(250), 14502(5), 14529(9), 14874(26), 15499(7), 15517(25), 15572(2), 15648(25), 15750(26), 16480(28)$, 
16554(26), 16637(10), 16667(27), 16888(18), 16983(5), 16994(23), 17062(24), 17779(24), 17786(10), 17787(20), 17793(25), 18144(15), 18479(25), 18661(25), 19248(10), 19602(1), 20777(6), 21537(26), 22386(22), 22597(7); 22927(25), 23359(11), 23440(2), 24789(12), 25920(25), 26536(20), 26902(24), 29251(28), 30951(1), 31761(25), 32278(8), 33678(20), 33891(22), 36625(26), 37302(22), 39176(22), 39963(2), 40364(24), 40415(22), 40758(25), 41929(2), 42234(24), 42722(20), 43468(25), 43650(19), 44528(20), 46835(1), 47829(10), 50331(2), 51483(19), 52135(10), 52285(1), 52574(2), 52806(2), 53227(24), 53682(7), 54335(8), 54799(1), 58456(16), 68275(24), 68318(12), 68662(19), 68774(25), 69847(7), 72320(24), 72737(3), 73845(10), 76815(22); Hoehne, F.C. s.n. SP 23459(24), SP 23496(22), SP 23324(26), SPSF 8955(31); Imaguire, N. 2170(20); Jarenkow, J.A. 2165(16); Jaster, C.B. 44(4); Kinupp, V.F. 223(4), 699(10), 741(24), 1129(25); Kita, K.K. 627(24); Klein, R. 1158(16), 2482(18), 2483(4), 2486(24), 4601(25), 10178(11), 11873(24); Koczicki, C. 265(22), s.n. MBM 12134(13); Koehler, A. 14(19); Kostin, A.J. 131(20); Kozera, C. 31(22); Kummrow, R. 1081(12), 2784(24); Kuniyoshi, Y.S. 3695(10), 4532(4), 4784(25), 5126(25), 6027(16); Lacerda, A. 161(24); Labiak, P.H. 2035(24), 3291(24), 3951(9); Landrum, R.L. 3939(2), 4086(23); Liebsch, D. 606(22), 704(22), 805(24); Lima, O.S. 10(19), 11(22); Lima, R.X. s.n. HFIE 2496(26), MBM 167476(26), UPCB 20731(26); Lindeman, J.C. 737(26), 975(5), 1285(7), 1794(7), 1810(26), 2146(13), 2200(26), 2382(2), 2733(26), 3088(5), 3126(24), 3309(7), 3401(24), 3422(25), 3443(7), 4877(26), 4921(7), 5255(20), 5284(7), 5323(10); Luchiari, C. 774(3); Mannu, M. 4(8); Marestoni, T.M. 18(31); Mariano, H. s.n. EFC 1124(20), EFC 1135(7), EFC 1137(24), EFC 1131(24); Maschio, W. 18(9), 37(19), 47(9), 71(20), 74(18), 233(9), 236(9), s.n. HFC 8002(4); Medri, M.E. s.n. FUEL 7990(22); Mikich, S.B. s.n. UPCB 33584(26); Mocochinski, A.Y. 56(22), 214(22), 216(28); Moreira, A.L.O.R. 150(26); Moreira, E. 361(27); Olinisky, I.A. s.n. HFC 8102(24); Oliveira, P.I. 600(24), Oliveira P.J. 527(24); Oliveira, V.P. s.n. MBM 261226(2); Paciornik, E.F. 230(19); Paiva, M.R.C. s.n. FUEL 21391(2), FUEL 26846(10); Pastore, J.A. 155(23) Pastore, U. 170(7); Paulino, E.G. 40(24); Pavão, O.C. 21(10), 251(25), s.n. FUEL 24713(7), MBM 304280(7), SP 377114(7), FUEL 37580(7), EFC 9558(24), FUEL 24712(24), FUEL 25067(26), HFC 5671(26), FUEL 25066(26), HFC 5670(26); Penna, P.M. 4(24); Pereira s.n. HUPG 16142(20); Pereira, E. 7719(25); Petenaci, A. 1178(23); Portes, M.C. 76(24); Poliquesi, C.B. 43(25); Possette, R.F.S. 222(22), 342(2); Pries, D. 16(25); Ramos, F.M. 27(10); Reginato, M. 173(29), 205(2), 607(25), 672(20), 695(9); Reitz, R. 568(9), 1846(9), 6676(8), 12093(26); Ribas, O.S. 5552(24), 5719(28), 6957(24), 7012(28), 7028(19), 7095(9); Richter, H.G. 104(7), s.n. EFC 10070(22), EFC 89(24), EFC 93(25), EFC 94(25); Roderjan, C.V. 65(1), 95(20), 426(7), 454(24), 786(10), 1130(22), s.n. EFC 10072(24); Romagnolo, M.B. 2071(7); Rotta, E. 170(16); Sá, K.L.V.R. 405(25); Sato, S. s.n. HUEM 1645(5); Santos, E.P. 1055(18), 1158(24), 1184(20); Saueressig, D. 1046(26); Scheer, M.B. 284(28); Schwarz, E.A. 609(24); Sekine, E.S. 163(24); Silva, A.D. s.n. UPCB 60213(22); Silva, C.A. da s.n. FUEL 20247(10); Silva, E.A. da 3589(7); Silva, E.M. s.n. HCF 5883(24), MBM 336816(24); Silva, F.A. s.n. FUEL 17298(10); Silva, J.M. 102(10), 604(25), 615(29), 723(28), 838(21), 938(22), 1839(2), 1966(2), 2110(27), 2262(26), 2467(5), 2524(30), 2724(25), 2848(11), 3082(1), 3113(27), 3327(28), 3350(19), 3357(21), 3580(8), 4105(28), 4269(28), 4346(24), 4398(3), 5996(20); Silva, P.S. s.n. HCF 2771(24), MBM 323044(24); Silva, R.M. 52(13); Silva, S.M. 1666(25), s.n. FUEL 12404(13), UPCB 32146(14), FUEL 12535(23); Soares e Silva, L.H. 22(5), 182(26), 189(23), 218(10), 1985(23); Souza, J.P. 83(3); Souza, L.A. s.n. UPCB 48851(10); Souza, L.R.M. s.n. FUEL 20948(2), MBM 270834(2), FUEL 21280(10), MBM 259010(10), FUEL 23257(12), MBM 283038(12), FUEL 24162(19), MBM 283042(19), FUEL 22220(19), SPSF 9810(19), FUEL 23279(22), FUEL 21279(23), HUPG 7299(23), MBM 230767(23), SPSF 9277(23), FUEL 22102(24), FUEL 22208(24), FUEL 22218(25); Souza, M.C. 1848(30); Souza-Stevaux, M.C. 359(7); Svolenski, A.C. 303(10); Takeda, I.Y.M. s.n. HUPG 6475(22); Tessmann, G. 3753(27); Tramujas, A.P. 96(19); Tomé, M.V.F. 361(26), 475(24), 724(20), 979(24), 1266(7), 1267(24); Viani, R.A.G. 19(7); Vicentini, A. 201(26); Völtz, R.R. 11(29); Ziller, S.R. 785(25), 939(25), 949(10), 983(26), 1015(4), 1026(7), 1035(24), 1245(25), 1530(22), 1697(25); Wanderley, M.G.L. 122(11); Wangler, M.S. s.n. HUCP 15192(24). 